NBER WORKING PAPERS SERIES

DEBT REDUCTION, ADJUSTMENT LENDING, AND BURDEN SHARING

Ishac Diwan

Dani Rodrik

Working Paper No. 4007

\author{
NATIONAL BUREAU OF ECONOMIC RESEARCH \\ 1050 Massachusetts Avenue \\ Cambridge, MA 02138 \\ March 1992
}

We would like to thank--without incriminating--John Wilton for helpful suggestions, and Dany Cassimon and Juergen Oedinius for research assistance. This paper is part of NBER's research program in International Studies. The findings, interpretations, and conclusions expressed in this paper are those of the authors and not those of the National Bureau of Economic Research or the World Bank, its Executive Directors or the countries they represent. 
NBER Working Paper \#4007

March 1992

\title{
DEBT REDUCTION, ADJUSTMENT LENDING, AND BURDEN SHARING
}

\begin{abstract}
We argue that the disincentive effect of a debt overhang is generally small and consequently that debt reduction does not lead to important efficiency gains on this account. Instead, we develop a framework that highlights the inefficiency created by the liquidity constraint faced by over-indebted countries. Often, adjustment/investment opportunities that are profitable at the world interest rate cannot be underaken for lack of sufficient funds. New creditors are deterred from investing as they expect to be "taxed" by the old creditors who stand to gain disproportionately. This leads to an inefficient situation when a class of new creditors have a comparative advantage relative to the old creditors. We focus on the time inconsistency introduced by the shortage of liquidity. New (unconditional) loans will be consumed rather than invested. In this context conditional lending can release the liquidity constraint in a time consistent way and lead to efficiency gains that can be shared between the debtor, the old creditors, and the new creditors. The role of debt reduction then is to create the "headroom" needed for these new and more efficient creditors to step in.
\end{abstract}

Ishac Diwan

The World Bank

1818 Street, N.W.

Washington, DC 20433
Dani Rodrik

Hoover Institution

Stanford University Stanford, CA 94305-6010 and Harvard University and NBER 


\section{Debt Reduction, Adjustnent Lending, and Burden Sharing}

\section{Introduction and Overolew}

The debt crisis of the eighties had many dimensions. The attention of policy makers focused first on the banking aspect of the crisis. A concerted response, led by the International Monetary Fund and the U.S. Federal Reserve. allowed the commercial banks to reduce their exposure and boost their loan loss reserves over time. By 1985, the banking sector was no longer in a state of imminent collapse, and attention focused on the developmental crisis of the highly indebted countries. Official intervention shifted to generating the incentives and support for policies that would allow the debtors to grow out of their debt crisis. By 1989, and although several countries were reentering a period of growth, it became clear that adjustment policies alone would not resolve the debt overhang. The burden of providing new money had shifted considerably to the International Financial Institutions (IFIs) (see tables 1 and 2), and a multilateral lending crisis loomed on the horizon. As a result, the IFIs were beginning to reduce their involvement and adjustment programs were failing for lack of sufficient financial support. The Brady plan, announced that year, emphasized for the first time debt reduction on the part of commercial banks, to be undertaken simultaneously with adjustment programs financed by additional loans from IFIs. Several debt packages have since bec: negotiated (in Mexico, Costa Rica, Philippines, Venezuela and Uruguay) based on these principles.

This paper focusses on two key aspects of the debt problem. First, is there a good rationale for the tripartite arrangements among commercial banks, IFIs, and debtor governments that we are now observing? To answer this question, we need to have a good understanding of the inefficiencies created by the debt crisis. Second, how do these arrangements split the costs and benefits among the participants? In other words, how does burden sharing work 
$-3-$

in these arrangements? In answering these questions, we will rely on a unified conceptual framework. Our objective, however, is to clarify the issues and the analytics, rather than to present the solution of a specific model of bargaining.

The conceptual underpinning of the need for debt reduction is provided by the notion of a "debt overhang", defined by Krugman (1987) as "the presence of an existing, 'inherited' debt sufficiently large that creditors do not expect with confidence to be fully repaid." The existence of deep market discounts on the debt of highly-indebted government is prima facie evidence of a debt overhang of this sort. This notion has been subject to much discussion, and has possibly contributed as much confusion as clarification. Another objective of this paper is to provide a systematic discussion of the issues raised by the debt overhang.

Our main points can be summarized in the form of answers to a series of specific questions:

\section{(1) Does the debt overhang have serious efficiency consequences?}

The real cost of the overhang is that many high-yielding investments in debtor countries go unexploited because these countries are shut out of credit markets and cannot borrow. This is the central inefficiency created by the debt crisis. The notion of investment has to be viewed broadly here. It refers to acummulation in human capital.-through spending on education and health--as well as in physical capital such as machinery and infrastructure. It also captures many types of policy reform, including structural reform and macroeconomic stabilization, whose long-term benefits may come at the expense of short-term costs. The liquidity shortage caused by the overhang leads to the crowding out of many such desirable investments in the country's future. 
$-4-$

Th1s 11liquidity effect on investment has to be distinguished from the "disincentive" effect on which much writing has focussed. The disincentive effect arises from the likelihood that an increase in the output of a country in overhang will lead also to an increase in its debt service. Therefore, the proceeds of domestic investment are shared, at least in part, with foreign creditors. In principle, this acts just like a tax on investment, decreasing the social return to domestic investment. However, there is no compelling conceptual reason to belleve that an aggregate "tax", if it exists, is internalized in private investment behavior: from the perspective of an individual investor, the aggregate transfer to creditors is an exogenous constant which is unaffected by the decisions of a small investor. Consequently, even if the social disincentive were large, the private disincentive would still be small.

The empirical importance of the disincentive effect is not clear either. For one thing, both the average and marginal tax rates implied by debt service are small: net transfers to creditors rarely exceed 4.5 percent of GNP, and the experience after 1982 has been that creditors can capture only about two cents out of any dollar increase in income (see table 3 , and the discussion in Eaton, 1990). In fact, there is no empirical evidence in cross. sectional studies, that a tax, no matter how small, is attached to the adjustment effort where the transfers to commerclal creditors is concerned (see table 3 ). Single-country investment equations (for example, Borensztein [1990] on the PhIlippines, Schmidt-Hebbel [1989] on Braz1l, and Morisset [1991] on Argentina) and panel regressions (e.g. Ozler and Rodrik [1991]) often find a negative relationship between indebtedness and investment. But it is possible that such results are driven by the correlation between growing debt and declining output in these countries in the 1980s, rather than by 
causality.

Hence, while the debt overhang is responsible for an investment shortfall, this shortfall is not the product of an artificial reduction in investment incentives but of a lack of liquidity.

\section{(2) If the central problen is lack of liquidity, is ner money alone}

\section{sufficient? Thy is debt reduction also needed to encourage nev investnent?}

Even though the chief inefficlency caused by the debt overhang is lack of liquidity, calls for new money and renewed lending are inadequate. The reason is that the overhang makes it impossible for countries to attract loans from new groups of creditors. In the absence of seniority, new loans enter the same pool as old loans and instantly metamorphose into as poor an investment as the old loans. Of course, these new loans may have led the country to undertake the investments it was previously unable to, and perhaps would also eliminate the overhang altogether. But as long as the old claims stand undiminished, the new lenders will have to share the fruits of any improved creditworthiness with the old lenders. This depresses the return to the potential new lenders, and keeps them from doing business with the debtor countries.

The consequence is that old creditors must provide debt relief in the form of debt or debt service reduction (DDSR) before a new class of creditors will put up new money. And if the new creditors, such as the IFIs, have a comparative advantage in eliciting the desired adjustments from governments, debt reduction will actually be beneficial to the old creditors themselves. In the presence of an overhang, therefore, both debt reduction and new money are needed to elicit new investment.

This argument depends critically on the presumption that new lenders 
$-6-$

cannot establish their seniority over existing claims. If lending by IFIs is senior to commercial bank claims, as it is sometimes argued, then the argument for debt reduction by commerclal banks would have to rely on incentive effects for the debtor rather than on burden sharing between the two types of creditors. Since we think the former has weak empirical basis, it is crucial for our argument that IFIs not be viewed as senior in the sense of a "mefirst" rule. For a good discussion of IFI senfority, the reader is referred to recent papers by Bulow and Rogoff (1991) and Demirguc-Kunt and FernandezArias (1991). Overall, both of these papers reach negative conclusions on IFI seniority.

(3) Thy are IFIs needed to arrange efficlent deals between creditors and debtors? Thy not leave the banks and governments to vork out their om efficlent debt agreements?

If IFIs did not provide something that commercial banks cannot, the case so far would be for banks (i.e., the main old creditors) to provide an appropriate new-money package to debtor governments such that the latter obtain the resources and the incentive to undertake the appropriate investments and adjustment. No DDSR would then be needed. Of course, banks would have to overcome the free-rider problem, in so far as the dominant strategy for an individual bank is to wait on the sidelines for others to put in the new money. But if the efficiency gains are large, such coordination problems can be overcome. Consequently, no new group of lenders would be needed, and IFIs could stay out of the whole business. Indeed, in the view of some observers official intervention is unnecessary, and the right thing to do is to "leave private debt hanging" (Bulow and Rogoff, 1990).

However, there is an efficiency-enhancing role for IFIs to play, and this 


$$
-7-
$$

is grounded in two functions that IFIs can perform better than commercial banks. The first is conditionality. IFIs can make their disbursements conditional on specific adjustments and policy reforms to be undertaken by the debtor government. They have a better capacity to monitor that the agreed measures are implemented, and are more acceptable to debtor governments. Secondly, IFIs simply know the debtor countries better. They have a better sense of the costs of adjustment (and hence of the magnitude of new money needed) and of whether governments will use the new money for investment or for consumption. In more technical terms, they have a comparative advantage in alleviating the asymmetric information that exists in the creditor-debtor relationship. It goes without saying that in neither of these roles is the performance of IFIs likely to be perfect. The point is simply that they are better at conditionality and fact-finding than commercial banks.

The practical consequence is that many mutually beneficial deals that would not have been struck by banks and debtors alone become feasible when IFIs are involved. Now, since banks are likely to demand that IFIs put their money where their mouth is, the appropriate role of IFIs involves a combination of conditionality, dissemination of information, and provision $\cdots$ additional loans.

(4) Why do debtor governments need conditionality to undertake reforms that are good for them?

One reason is that the presence of a debt overhang acts as a tax on adjustment effort, just as it acts as a tax on investment. But as discussed above, the practical significance of this is likely to be limited. Besides, if a combination of DDSR and new money eliminates the overhang, the disincentive for adjustment disappears also. 
$-8-$

The more important reason is that a liquidity constrained country is by definition one in which it would be desirable to transfer resources from the future to the present (at the tradeoff represented by the world interest rate). A typical adjustment program would entail costs upfront and benefits down the line, and would transfer income to the future rather than the present. Therefore, a program that would be undertaken in the absence of a liquidity constraint--i.e., a "worthwhile" program--will not necessarily be undertaken unless there is sufficient external financing. Generally speaking, there will be a level of external financing, call it $L^{*}$, at which a government will choose to undertake adjustment even in the absence of conditionality. Then there will be a lower level of financing, call it $L_{c}^{*}$, at which the government would choose to adjust only if the financing is contingent on adjustment--1.e., if there exists conditionality. If commercial banks can come up with $L^{*}$ but not $L^{*}$, the country would take the money but not adjust. Knowing that, banks are unlikely to lend $L_{c}^{*}$ in the first place. Note the debtor government's time-inconsistency problem: it would be better off using $L_{c}^{*}$ for adjustment than not getting $L_{c}^{*}$ at all, but once it has $L_{c}^{*}$ it would rather use the loan for consumption.

What conditionality buys in this instance is the commitment to adjust, which the country is unable to provide on its own for standard credibility reasons. With conditionality, the banks and the country are potentially both better off. For the debtor government, conditionality prevents the best from being the enemy of the good.

(5) How does the Involvement of IFIs affect the returns to banks and the rellbeing of debtor countrles?

As discussed above, there is a wide range of circumstances in which the 
involvement of IFIs can make both the debtor and the creditor banks, collectively, better off. IFI conditionality buys the debtor credibility, and that in turn makes the commercial banks willing to provide DDSR. There are efficiency gains from this three-way exchange, and there exist many different ways of splitting these gains among the commercial creditors, the debtor country, and the IFIs themselves. Any desired division between the three parties can be achieved by an appropriate selection of: (i) the amount of the new loan recelved by the country (L) in return for adherence to an adjustment program; (ii) the share of the new loan that is provided by each of the two creditor groups; and (iii) the sharing--between the two creditor groups--of the future repayment made by the country. The higher is $L$, the better off is the country. The commercial banks are better off (and the IFIs worse off) when the banks have to provide a smaller share of $L$ and when they get a larger share of the future repayment. Of course, the constraint that the banks, the debtor, and the IFIs be at least as well off with a deal than without it limit the range of combinations.

We will show that even when such efficiency enhancing packages are implemented, such packages alone will not be sufficient to resolve the debt overhang. Often, future debt service repayments will still be expected to fall below their contractual value. The effective repayments made by the country will thus have to be divided in some manner between the different creditors. Under equal seniority, the total debt repayment will be divided between creditors on the basis of their share of total claims. In such a case, the new credits to support adjustment cannot be expected to be fully repaid and the benefit of the program will partially accrue to the old creditors.

But the participation constraints limit the ways in which the net benefit of the program--that is, the increase in the total debt payments minus the 
$-10-$

loss on the loans that need to be provided to support adjustment--is divided between the commercial banks and the IFIs. Any particular sharing of the cost between the two creditor groups can be achieved by varying the shares of their new money contribution. And the sharing in the benefit can be altered by varying the shares in total debt of each group's debt claims.

When the IFIs have no prior exposure to the debtor country, but are expected to provide new money to support an adjustment program, the banks must provide enough debt relief to return the country to creditworthiness and allow the IFIs to make a "normal" return on their Investment. But when the IfIs have some prior exposure to the country, adfustment lending also improves the IFIs' ablilty to collect on their old debts. This reduces the amount of rellef that needs to be offered by banks. As a result, however, there is no compelling reason to return the country to creditworthiness. Indeed, if the debt overhang were to be eliminated, the IFIs would get a normal return on their new and old loans, while the banks would only get a normal return on the part of the1r debt that had not been forgiven. While this may still be a situation preferable to that without adjustment, the banks may insist on a fairer sharing of the net gains.

As a benchmark, it is useful to consider a proportional distribution rule (PDR), where the net gains are divided between the creditors proportionally to their inftial exposure. For reasons stated above, the PDR is incompatible with the complete elimination of the overhang as long as (i) IFIs do not provide debt reduction, and (ii) IFIs have prior exposure to the problem debtor. Since both conditions hold in practice, a rule such as PDR intereferes with return to creditworthiness.

To the extent that the IFIs can claim that the net benefits of the program derive from their own actions (i.e., the provision of conditionality), 
-11 .

they may demand that the banks grant more debt relief than that implied by the PDR. But to the extent that banks can bargain harder by threatening to delay the program, and to the extent that IFIs' loans enjoy a preferential treatment by the creditors, less debt relief will be forthcoming.

The same considerations apply when debt relief is provided by the banks through buybacks (rather than pure debt relief). Buybacks allow banks to cash in part of their share of the net benefit of the program early on. Under the PDR rule, the larger the exit price, the more do banks need to give up future repayments, and thus, the larger the needed debt reduction.

\section{(6) Bow is burden sharing accomplished under the Brady Plan?}

While the Baker plan stressed the need to increase financial support, especially from the IFIs, it was clear by 1989 that new loans from commercial sources had dried up. Net transfers from the SIMICs ${ }^{2}$ to the commercial banks stood at over $\$ 15$ billion for a sixth year in a row. Possibly as a reaction to the unfavorable sharing of the burden, the IFIs also decreased their lending activities to the highly indebted countries, with net transfers becoming negative starting in 1987 (see table 2).

The Brady plan stressed the need for debt reduction by commercial banks in the context of adjustment programs funded by the IFIs. It also recognized the diversity of interests that characterized the banking community, still adjusting to the interest rate shock of the early 1980 s and adapting to increased competition from less regulated financial institutions. The Plan

\footnotetext{
${ }^{1}$ Severely Indebted Middle Income Countries. See table 1 for a list.
} 
$-12-$

stressed market based deals, using the emerging menu approach to debt rescheduling to allow for diverse responses by banks.

If debt is repurchased on the secondary market, the price that must be paid is the equilibrium price of debt claims after the debt reduction. Under such a mechanism, the exiting banks would not have to share the burden of financing adjustment. As a result, deals with "fair" burden sharing (e.g. with PDR) cannot rely on market buybacks to achieve the desired debt reduction. Rather, concerted debt reductions need to be worked out to overcome this coordination failure. Ideally, each creditor bank would sell a specific share of its claims at a price below the expected ex-post price. But in practice, it may prove difficult to achieve much debt reduction in such a manner, principally because of the heterogeneity within the banks' group. If creditors differ with respect to their own relative valuation of country debt, a concerted buyback that does not discriminate between banks and that at the same time hurts no bank must occur at the reservation price of the bank with the highest valuation. On this score, the market mechanism is more efficient In that it allows creditors to self-select, with only those with low valuation selling out at a particular offer price.

The recent Brady deals have focused on a menu of options from which the creditors will select later. By combining concerted and voluntary characteristics, the menu approach to debt reduction retains the advantages, but not the inconveniences, of pure market and pure concerted mechanisms described above. The options on the menu and their relative pricing are first negotiated; in a second round, each creditor freely chooses his preferred option. Overall, the discrimination allowed by the menu allows for larger actual relief, for a given willingness of banks to offer relief.

For a menu of options to allow different creditors to choose different 
options voluntarily, the value of all options must be comparable. This works out mechanically when the menu includes exit and relending options, because each of these options becomes more valuable as the other option is picked by too many banks. In equilibrium, all options will have comparable values.

If the IFIs are treated symmetrically with the banks that choose to offer new money, any menu of options that includes exit and relending options will also obey the proportional distribution rule. But only the menus with a particular exit price (the "fair" price, r) will raise sufficient liquidity to support the adjustment program. On the other hand, the sharing of the net cost of the program among all creditors will not be proportional if the IFIs' new money contribution is relatively larger than that of banks that chose to relend and remain exposed to the debtor country.

In the following, we will discuss and illustrate these points using an analytical framework. Our starting point is the problem faced by a government with a debt overhang which has to choose whether to undertake an adjustment program or not. Adjustment has the potential of eliminating the overhang, but, in the absence of external financing, the immediate costs would be too high relative to future benefits. We then look at the set of strategies avaflable to commercial banks and characterize the types of arrangements that the banks and the country could work out by themselves. Next, we introduce conditionality on the part of IFIs, and analyze the enlarged set of deals that this makes possible. Finally, we look at various strategies for dividing the efficiency gains among the IFIs, commercial banks, and the debtor under Bradytype deals.

II The Adjustment Decision 
$-14-$

There are two key features in the way we view adjustment policles followed by debtor countries. The first, for analytical convenience mostly, is that adjustment is an all-or-nothing affair. Governments either choose to adjust or they don't. This rules out the possibility, which certainly exists in reality, that a varying amount of adjustment effort may be exerted depending on the circumstances. However, since we will view the adjustment decision as the consequence of rational cost-benefit calculus, treating the decision as a binary one has also some practical benefits. For one thing, it leads to more realism than the smooth case in which the marginal costs and benefits of adjustment effort are continuously balanced, and the country gains nothing--thanks to the envelope theorem--from an increase in adjustment induced by a change in, say, external lending. Moreover, this formulation allows us to downplay the "adjustment tax" aspect of the debt overhang, which as we argued in the preceding section has little empirical content.

The second feature, which is critical to the story that follows, is that adjustment requires incurring some fixed costs upfront. The benefits of adjustment come not immediately, but over time; in the context of a two-period model, they arrive in the second period. This is a realistic aspect of most policy reforms. On the stabilization front, any program that works is likely to be recessionary in the short run. With respect to structural reforms, they too typically create costs in the short run, either economic or political. It is this feature which makes adjustment programs formally identical to investment: in each case, a cost is incurred to reap a reward in the future. For example, the countries that have undertaken adjustment programs with intensive support from the IMF and the World Bank have lost on average 5.1 percent of output in the first year of the program, 4.7 percent in the second year, and 2 percent in the third year (see table 4). While these estimates 
$-15-$

correct for trend growth and terms of trade shocks, they should be taken with a grain of salt. On the one hand, they are blased upward since these countries would have lost growth opportunities by not adjusting. Indeed, output fell by an average of 3.1 percent in the year prior to the adjustment program, and 2.4 percent two years before the beginning of adjustment. But on the other hand, it is likely that countries that ajust are those where adjustment costs are the lowest. The selection bias is thus likely to lower these estimates. The government starts out with an inherited debt which carries a face value of $D$. In period zero, it is offered a package from the commercial banks, which consists of debt reduction of amount $B$ and new loans of amount $L$. In the next section, we will look more closely at the banks' incentive to offer some debt relief; for the moment, we take $B$ and $L$ as given. On the basis of this package, the government decides whether to undertake an adjustment program or not. Adjustment "costs" a fixed amount $\mathrm{K}$ in period zero, but increases output from $Y$ to $Y(1+\theta)$ in period one. The government enters period one with an existing stock of debt amounting to $R[D-B+L]$, where $R$ is one plus the world interest rate. If it fails to repay the debt in full, creditors are able to penalize the country by a fraction, $\alpha$, of output. The presence of an overhang is ensured by assuming that the country would never choose to repay the debt in full in the absence of adjustment and/or debt reduction, i.e. $\mathrm{RD}>\alpha \mathrm{Y}$.

The government seeks to maximize a welfare function where second-period utility is linear in consumption:

(1) $\quad \operatorname{Max} W-U\left(C_{0}\right)+\beta C_{1}$

$$
\text { s.t. } \quad C_{0}- \begin{cases}Y+L-K, & \text { if adjust } \\ Y+L, & \text { otherwise. }\end{cases}
$$


-16 -

$$
C_{1}= \begin{cases}\max (Y(1+\theta)-R[D-B+L],(1-\alpha) Y(1+\theta)), & \text { if adfust } \\ \max (Y-R[D-B+L],(1-\alpha) Y), & \text { otherwise. }\end{cases}
$$

Note that for completeness we have allowed for the possibility that the overhang may be elfminated even in the absence of adjustment (thanks to a large enough $B$ ), even though banks will have no incentive to provide DDSR in such a case. In what follows, we will assume that the government remains credit rationed in all relevant cases, so that it views increases in $L$ as always desirable. This is guaranteed by assuming $U^{\prime}>\beta R$ throughout. Note that commercial banks have no control over what the government chooses to do with L. So they cannot make the provision of $L$ (or $B$ ) contingent on that choice. This is reflected above in that $C_{0}$ equals $Y+L$ rather than $Y$ when the government chooses not to adjust. Once the loan is provided, the government simply chooses whatever is good for itself. Under conditional lending (discussed below), the government would be forced to adjust whenever $L$ $>0$.

Substituting for $C_{0}$ and $C_{1}$ in the maximand, we can express the government's decision rule as follows:

$$
\text { Adjust if: } \begin{aligned}
U(Y+L-K)+\beta \max \{Y(1+\theta)-R[D-B+L],(1-\alpha) Y(1+\theta)) \\
\geq U(Y+L)+\beta \max (Y-R[D-B+L],(1-\alpha) Y\}
\end{aligned}
$$

As this makes clear, the net benefits of adjustment are sensitive to whether the debt overhang is eliminated in period one or not. If it is, consumption in period one becomes $Y(1+\theta)-R[D-B+L]$ or $Y-R[D-B+L]$. If the overhang continues, consumption in period one is independent of both $L$ and $B$, and equals $(1-\alpha) Y(1+\theta)$ or $(1-\alpha) Y$. The cost-benefit calculus therefore shows different properties depending on the overhang status. 
There are four possibilities for the outcome in period one, each of which describes a different zone in $(B, L)$ space:

Zone I: no adjustment, no overhang;

Zone II: adjustment, no overhang;

Zone III: adjustment, overhang;

Zone IV: no adjustment, overhang.

For each combination of $B$ and $L$, the government's adjustment decision puts us in one of these four zones. These zones are deplcted in Figure 1.

To see how we get these zones, consider first the demarcation between overhang and no-overhang zones. This demarcation is defined by the combinations of $B$ and $L$ that leave the government indifferent between repaying the debt in full and paying the penalty ( $\alpha$ times output). Hence it is described by the following equations:

\footnotetext{
$R[D-B+L]-\alpha Y(1+\theta)$, when adjusting

and $R[D-B+L]-\alpha Y$, when not adjusting.
}

Note that these are two 45-degree lines, with the first being the relevant one in zones II and III, and the second the relevant one in zones I and IV. They capture the following simple intuitions. First, when the government is just short of default, an additional dollar of new lending has to be offset by an additional dollar of debt reduction to keep the government from crossing over. Second, when the government chooses to adjust (and output rises to $Y(1+\theta)$ ), the no-overhang region becomes larger and the overhang region smaller.

Turn now to the loci that separate the adjustment zones from the noadjustment zones. The relevant locus is easy to describe when an overhang prevails. Here we have the equality 
.18 .

$$
U(Y+L-K)+\beta(1-\alpha) Y(1+\theta)-U(Y+L)+\beta(L-\alpha) Y,
$$

Or:

(3) $U(Y+L) \cdot U(Y+L-K)-\theta(1-\alpha) \theta Y$.

This defines implicitly a level of $L, L^{*}$, which makes this equality hold.

When the country remains in overhang, the government will choose to adjust for all $\mathrm{L}$ greater or equal to $\mathrm{L}^{*}$. $\mathrm{L}^{*}$ can be written as a function of the various parameters in (3):

(4) $L^{*}-L^{*}\left(\dot{\alpha}, \dot{\theta}, \dot{\beta},+\mathrm{K}^{+}\right.$.

It can be checked that the minimum loan needed to make the government choose adjustment (when overhang continues) is increasing in $a$ and $K$, and decreasing in $\beta$ and $\theta$ (as long as $U^{\prime \prime}<0$ ). These axe intuitively appealing results.

Note moreover that $L^{*}$ does not depend on $B$, as the face value of the Inherited debt stock is of no consequence as long as overhang prevails. Therefore, the demarcation between zones III and IV (adjustment and no-adjustment zones, both in overhang) is a perfectly vertical line as shown in Figure 1.

The corresponding locus in the absence of overhang is more tricky.

Consider the situation where the government would be in overhang if it did not adjust, the relevant case for much of the subsequent discussion. Now adjustment requires

or:

$$
\begin{aligned}
U(Y+L-K)+\beta(Y(1+\theta)-R(D-B+L]) \\
\geq U(Y+L)+\beta(1-\alpha) Y,
\end{aligned}
$$

(5) $U(Y+L)-U(Y+L-K)+R[D-B+L] \leq(\alpha+\theta) \beta Y$.

When equation ( 5 ) holds as an equality, it defines a schedule along which the 
$-19$.

government remains indffferent between adjusting and not adjusting. The relation between $\mathrm{L}$ and $\mathrm{B}$ along this schedule is given by:

$$
d L / d B-1-(\beta R)^{-1}\left[U^{\prime}(Y+L-K)-U^{\prime}(Y+L)\right],
$$

which is of ambiguous sign since the expression in the square brackets is positive as long as $U^{n}<0$.

The explanation for the amblguity is as follows. A dollar increase in $B$ increases the net benefit from adjusting by $\beta$ R dollars (since this is the discounted present value of the increase in second perfod consumption when adjusting). Should $L$ be increased or decreased to offset the added incentive to adjust? Now an increase in $\mathrm{L}$ would reduce the benefit of adjusting to the extent that the discounted second period consumption would fall. (Since overhang prevails when not adjusting, $L$ does not affect consumption in period one when the government chooses not to adjust.) But an increase in $L$ would also reduce the net cost of adjusting to the extent that consumption can be better smoothed. If the first effect dominates the second-.i.e., $\beta R>\left[U^{\prime}(Y+\right.$ $\left.L-K)-U^{\prime}(Y+L)\right] \cdot-L$ should be increased. Otherwise, $L$ should be reduced. Figure 1 shows three possibilitites: ${ }^{2}$ in Figure $1(a), d L / d B$ is initially negative in the relevant range, and then turns positive; in Figure $1(b), d L / d B$ is negative throughout; and in Figure $l(c), d L / d B$ is positive throughout.

There is one final case to consider in completing the description of Figure 1, and that is the case where the government would not be in overhang

2. As long as $U^{\prime \prime}>0$, these are the only possibilities. 
-20 .

even when it falled to adjust. The locus that describes indifference to adjustment in this case is given by the following equality:

(7) $U(Y+L)-U(Y+L-K)-\beta \theta Y$.

This defines implicitly a level of $\mathrm{L}, \mathrm{L}^{* *}$, which makes this equality hold. This is independent of $B$ (as is $L^{*}$ ), and it is easy to check that $L^{* *}<L^{*}$. This explains the vertical line that separates zone III from zone I in Figure 1.

Figure 1 completely describes government behavior and the consequent overhang status in response to any combination of debt reduction ( $B$ ) and new money (L). Several things are noteworthy here. First, note that the country will always choose to adjust for a sufficiently large amount of new lending. even in the absence of conditionality (as is assumed here). The reason is that adjustment is, by assumption, a good bargain for the country when it can borrow at world interest rates. An additional reason is that when the country ends up in overhang, as it will for large $L$, it does not have to pay the loan back. Second, and more obviously, a large enough debt reduction will always eliminate the overhang.

But to eliminate the overhang and get the government to adjust (zone II), the country needs both new money and debt reduction. One alone will not do the trick. New money tends to enhance the incentive to adjust by alleviating the short-run costs, but renders overhang more likely down the line. Debt reduction works against the overhang, but has uncertain benefits with regard to the adjustment incentive: in terms of Figure 1, debt reduction increases the adjustment likelihood only when $L$ lies between $L^{* *}$ and $L^{*}$. The appropriate strategy, therefore, will involve a bit of both. 


\section{That Kind of Creditor-Debtor Deals Are Possible?}

Let us assume that commercial banks can overcome the coordination problem inherent in their interaction with the debtor government and can act collectively. We should expect them to be aware of the possibility (portrayed in Figure 1) that they can influence the behavior of the government by providing it with an appropriate package of new money and debt reduction. When wlll they have the incentive to offer such a package, and what would the package look like? In other words, when can the debtor government and the banks reach mutually-advantageous bargains in the absence of the IFIs? The answers to these questions will provide the benchmark against which the possible bargains with IFI involvement can be measured.

Let us first discuss the returns to banks in different zones of Figure 1. When the country is in overhang, the face value of the debt outstanding is irrelevant to the banks' profits. Their profits in period one can therefore be written as:

(8) $\pi(B, L)= \begin{cases}\alpha Y(1+\theta)-R L, & \text { when the country adjusts (zone III) } \\ \alpha Y-R L, & \text { otherwise (zone IV). }\end{cases}$ Note that this is independent of $B$, as $B$ affects only the face value of the debt as long as the overhang is still in effect. Also note that the opportunity cost of the new money, RL, should be subtracted from period one profits. Giving new money may make sense to the banks only if this makes the country adjust. Expression (8) makes it clear that the banks iso-profit curves in zones III and IV are vertical lines which represent increasing profits as they come closer to the origin.

In the no-overhang zones, bank profits in period one are given by: 
(9) $\pi(B, L)-R[D-B] \quad$ (zones I and II).

Note that $L$ does not enter this expression because we assume that the interest charged on the new loans match the opportunlty cost of funds, making banks Indifferent to lending when they can recover their money. We could have assumed that banks make excess profits on their loans to creditworthy clients without altering any of the subsequent qualitative results. In any case, expression (8) makes bank iso-profit curves horizontal lines in zones I and II, with lower lines representing higher profits.

To abstract from bargaining issues, let us suppose that banks move first and can make a take-it-or-leave it offer to the country. What will they choose to do? Banks will offer one of three types of packages:

(1) No deal. This is represented by the origin in Figure 1 , with $B-L$ - 0 . In this case, the government chooses not to adjust, and the country remains in overhang. Incidentally, a small amount of debt reduction (small in that it does not push us into zone I) would not hurt the banks or benefit the country, as it does not affect the repayment in period one. ${ }^{3}$

(ii) The banks offer a package that consists of new money amounting to $L^{*}$ and a range of debt reduction anywhere between zero and $B^{*}$. One such package is shown as the point $X$ in Figure $1(b)$. Now the country gets enough financing to adjust. But the banks are 1ndifferent as to whether the overhang is

3. This is due to the absence of uncertainty. When period one outcomes are uncertain, hanging on to the higher face value has an option value for the banks which arises from the possibility that the debt will be serviced in full in some good state of nature. 
eliminated or not, the reason being that in either case they can get no more that $\alpha Y(1+\theta)$ out of the country. This explains why banks are indifferent between providing debt reduction of $\mathrm{B}^{*}$ (which is the minimum needed to eliminate the hangover) and no debt reduction at all-.or anything in between. (iii) The banks offer a package that consists of $\hat{L}\left(<L^{*}\right)$ and $\hat{B}\left(<B^{*}\right)$, which is just enough to eliminate the hangover and get the country to adjust. This package is shown as the point $Y$ in Figure $1(a)$. This package puts us just inside zone II, and eliminates the hangover while ensuring adjustment. Alternatively, they offer $L^{* *}\left(<L^{*}\right)$ and $B^{* *}\left(<B^{*}\right)$, shown as point $Z$ in Figure 1(c), which has the same features. In either of these cases, the bank makes more profits than with the package $\left(\mathrm{B}^{*}, \mathrm{~L}^{*}\right)$. Note, however, that such packages are feasible only when the border separating zones II and IV either has an interior minimum, as in Figure l(a), or is positively sloped throughout, as in Figure 1(c). The reason banks want to ensure that the overhang is eliminated in this case, unlike in ( $1 i$ ) above, is that otherwise the country would rationally choose not to adjust. (A slight reduction in $B$ starting from points $Y$ or $Z$ would put the country in a no-adjustment zone).

In sumary, the alternatives are: (i) no deal; (ii) a package that ensures adjustment but is indifferent to eliminating the hangover; and (iii) a package that ensures both adjustment and return to creditworthiness. One of these three will dominate all other possible deals.

The next question is what determines whether a package like (ii) and (iii) dominates the no-deal option. Consider profits when the package ( $B^{*}$, $\left.L^{*}\right)$ is offered. Bank profits are now $\pi\left(B^{*}, L^{*}\right)-\pi\left(0, L^{*}\right)-\alpha Y(1+\theta)-R L^{*}$. With no deal, banks get $\pi(0,0)=\alpha Y$. Therefore, the condition for the package to be offered is $\alpha Y(1+\theta)-\mathrm{RL}^{*} \geq \alpha Y$, implying 
This says that the minimum amount of new money required to make it worthwhile for the country to adjust must be less than the discounted value of a fraction of domestic resources, where the fraction equals the product of the productivity improvement and the maximum share of domestic resources extracted by creditors. If $L^{*}$ falls short of this value, banks will be willing to offer a deal. The condition has a stralghtforward intuitive explanation. Banks can extract at most a fraction, $a$, of the increment in domestic output, $\theta Y$, when the country adfusts. They have no incentive to spend more than this amount to "purchase" adjustment.

As mentioned above, alternative packages such as $(\hat{L}, \hat{B})$, and $\left(L^{* *}, B^{* *}\right)$, when they are feasible, provide the bank with higher profits than the package $\left(L^{*}, B^{*}\right)$. Therefore, the condition expressed in (10) is a sufficient but not necessary condition for a mutually-beneficlal deal to exist. High values of $\theta$ and $\beta$, and low values of $K$ make it easier for the condition to be fulfilled, while the effect of $\alpha$ is ambiguous."

What kind of practical guidance does (10) provide as to the likelihood of mutually advantageous deals? The right-hand side of the inequality above depends on two critical parameters, $\alpha$ and $\theta$, both of which are in principle observable. For $\alpha$, a range of 1 to 4 percent of GDP would seem a reasonable one for most highly-indebted countries. $\theta$, which measures the permanent

4. The ambiguity with respect to $\alpha$ is explained as follows. An increase in $\alpha$ increases the extraction by creditors, but for the same reason increases the threshold $\mathrm{L}$ at which debtor becomes willing to adjust. 
productivity benefit of adjustment, can be estimated by conventional techniques, such as those used at the World Bank and the IMF. Let us assume, to be generous, that adjustment can increase the level of output permanently by something in the range of 10-40 percentage points.

Putting all these pieces together, we get the numbers shown in Table 5 which express the sufficient condition (10). (For purposes of these calculations, $R$ is taken to be 1.1 ) The way to read the table is as follows: When $\alpha$ is 2 percent, for example, the largest increase in exposure banks are willing to accept during the whole adjustment period in return for a 20 percent permanent increase in the debtor's income is 0.36 percent of the country's GDP. If new money of this amount is enough to make the country undertake the required adjustment, once the money is disbursed, then banks will be willing to offer such a package. Since adjustment episodes cannot be expected to succeed in less than 3-5 years, the numbers in the table must be divided by a factor of 3 to 5 to yield the maximum annual disbursement to GDP that banks will be willing to offer. Therefore these illustrative calculations are not encouraging with respect to the likelihood that banks and debtor countries will discover mutually-advantageous bargains on their own. As we will see in the next section, the presence of conditionality may relax the constraint substantially.

\section{How Does Conditionality Change Things?}

Commercial banks have little control over how their loans are used, once disbursed. Political circunstances in debtor countries would scarcely allow them to exercise much influence over domestic policies. Nor would promises by governments to undertake the requisite adjustment be credible if the net benefits to adjusting remain negative after the funds are disbursed. 
-26 -

Therefore, banks will be willing to spend new money only when they are fairly certain that the money will be decisive in tilting governments' incentives to adjust. However, as the examples above show, the amount needed may be much too high in relation to the eventual return to the banks.

Conditionality changes the nature of the bargain between creditors and the debtor government. It makes the package conditional on adjustment being undertaken. Now the cost-benefit calculus of the government is altered: it has to compare the cost of adjustment against the cost of having to give up external financing. When the choice is between adjusting with new money and not adjusting without new money, it will take a lower amount of external financing to purchase adjustment compared to the case where new money is disbursed in elther case. Moreover, the country will typlcally be better off with such conditionality also, as the alternative may well be no deal at all. For similar discussions on conditionality, see Sachs (1989) and Claessens and Diwan (1991).

To see what difference conditionality makes in our framework, we recast the government's optimization problem making $L$ available only when adjustment is chosen:

$$
\begin{aligned}
& \operatorname{Max} W-U\left(C_{0}\right)+\beta C_{1} \\
& \text { s.t. } C_{0}= \begin{cases}Y+L-K, & \text { if adfust } \\
Y, & \text { otherwise. }\end{cases} \\
& C_{1}= \begin{cases}\max (Y(1+\theta)-R[D-B+L],(1-\alpha) Y(1+\theta)), & \text { if adjust } \\
\max \{Y-R[D-B],(1-\alpha) Y\}, & \text { otherwise. }\end{cases}
\end{aligned}
$$

The only difference here from (1) is that $L$ does not affect $C_{0}$ or $C_{1}$ in the non-adjustment states. The government's decision rule then becomes: 
(2') Adjust if: $U(Y+L-K)+\beta \max (Y(1+\theta)-R[D-B+L],(1-\alpha) Y(1+\theta))$

$$
\geq U(Y)+\beta \max (Y-R[D-B],(1-\alpha) Y\}
$$

We can now proceed to determine the four zones of possible outcomes as before.

Since conditionality affects only the incentive to adjust, and not the demarcation between overhang and no-overhang zones, we focus exclusively on the former.

In the presence of an overhang, the locus that separates the adjustment zone from the no-adjustment zone is given by

(3') $U(Y)-U(Y+L-K)-\beta(1-\alpha) \theta Y$.

This defines implicitly a level of $L, L^{*}$, which makes this equality hold. $\mathrm{L}_{c}^{*}$ has the same qualitative properties as $\mathrm{L}^{*}$, except that $\mathrm{Lt}$ is always lower (as can be seen by comparing this expression with $\left[3^{\prime}\right]$ ):

(4') $\quad \mathrm{L}_{c}^{*}-\mathrm{L}_{\mathrm{c}}^{*}\left(\alpha, \dot{\theta}, \beta,+\mathrm{K}^{+}\right)<\mathrm{L}^{*}$.

Consider next the situation where the government would be in overhang if it did not adjust but not otherwise. Now adjustment requires

$$
\begin{array}{r}
\mathrm{U}(\mathrm{Y}+\mathrm{L}-\mathrm{K})+\beta(\mathrm{Y}(1+\theta)-\mathrm{R}[\mathrm{D}-\mathrm{B}+\mathrm{L}]) \\
\geq \mathrm{U}(\mathrm{Y})+\beta(1-\alpha) \mathrm{Y}
\end{array}
$$

or:

(5') $U(Y)-U(Y+L-K)+R[D-B+L] \leq(\alpha+\theta) \beta Y$.

The relation between $L$ and $B$ along this schedule is given by:

(6') $d L / d B-1-(\beta R)^{-1} U^{\prime}(Y+L-K)<0$,

with the negative sign unambiguous as long as the government remains liquidity 
-28 -

constralned (1.e., $U^{\prime}>\beta \mathrm{R}$ ). Hence, unlike in the no-conditionality case, an increase in $L$ always increases adjustment incentives in this case (cE. [6]). This and the earlier schedule under no conditionality (5) are related as follows: (i) the two meet when $L=0$; and (ii) the schedule with conditionality always lies below the no-conditionality schedule.

Finally, consider the case where the government would not be in overhang even when it failed to adjust. The locus that describes indifference to adjustment in this case is given by:

(7') $U(Y)-U(Y+L-K)-\beta \theta Y$,

which defines implicitly a level of $L_{,} L_{c}{ }^{* *}$, which makes the equality hold.

Once again, this is lower than the corresponding level under no conditionality, $\mathrm{L}_{\mathrm{c}}{ }^{* *}<\mathrm{L}^{* *}$.

Figure 2 shows the new configuration and how it relates to its analogue in the absence of conditionality. The main thing to notice here is that the two adjustment zones (II and III) have expanded. Zone II (adjustment and no overhang) is now larger by the single-hatched area, and zone III (adjustment with overhang) is now larger by the double-hatched area. The implication is that lower levels of new money and debt reduction are required to get the country to adjust and eliminate the overhang in the presence of conditionality.

Now consider the type of package that banks might be willing to offer to the government when conditionality is in effect. The relevant options are now two-fold: (i) no deal $(L-B-0)$; and (ii) a package that consists of $L$ $L^{*}$ and $B \in\left[0, B_{c}^{*}\right]$. Other options are dominated by one of these two for the following reason: bank profits are increasing in the southern direction in zone II and the slope of the border separating zones II and IV is 
unambiguously negative under conditionality. The condition for (if) to be preferred to (i) by the banks is anologous to the previous condition, namely $\left(10^{\prime}\right) \quad \mathrm{L}_{c}^{*}(\alpha, \theta, \beta, \mathrm{K}) \leq \alpha \theta \mathrm{Y} / \mathrm{R}$.

Now, since $\mathrm{L}_{\mathrm{c}}<\mathrm{L}^{*}$, this is a less restrictive condition than the one in the absence of conditionality. In other words, conditionality expands the range of mutually-beneficial bargains between banks and the debtor government.

Can we say anything about the size of the gap between $L_{c}^{*}$ and $L^{*}$ ? For conditionality to make any real difference in practice, the gap has to be a meaningful number. To get at this issue in a rough way, we can first combine (3) and (3') to write:

$$
U\left(Y+L^{*}\right)-U\left(Y+L^{*}-K\right)-U(Y)-U\left(Y+L_{e}^{*}-K\right)
$$

Now assume that utility is logarithmic. Rearranging terms, we get:

$$
\log \left(Y+L^{*}\right)-\log Y-\log \left(Y+L^{*}-K\right)-\log \left(Y+L_{c}^{*}-K\right)
$$

We can interpret each side of this equality as approximating a percentage change. As long as $L^{*}$ is small relative to $Y$, this will not a bad approximation. Hence:

$$
L^{*} / Y=\left(L^{*}-L_{c}^{*}\right) /\left(Y+L_{c}^{*}-K\right)
$$

which yields after simplifying:

(11) $L^{*}{ }_{c}^{*}-K /\left(Y+L^{*}\right)$.

Therefore, the ratio of $\mathrm{L}^{*}$, to $\mathrm{L}^{*}$ is roughly of the order of the short-run adjustment cost relative to GDP. As it is difficult to imagine that adjustment costs would exceed 10 percent of income, $L^{*}$ should normally be 
quite a small fraction of $L^{*}$.

Hence, if this 1llustrative calculation is any guide, conditionality can make a big difference indeed--at least when it is effective. It considerably enlarges the parameter space within which a mutually-advantageous bargain is possible.

One advantage of IFI participation, therefore, is the provision of conditionality. Another, as mentioned in the introduction, is better information. For mutually-advantageous bargains can be ruled out not only by the inability of the government to credibly commit itself to adjustment (in the absence of explicit conditionality), but also by asymetric information. The commercial banks are poor judges of the cost of adjustment $(K)$ or the productivity enhancement $(\theta)$ to be experienced by different countries. Under asymetric information of this sort, they are likely to be more conservative in spending new money than they would have been under complete information. All the more so since debtors will have the incentive to "cheat" by claiming low $\mathrm{K}$ or high $\theta$, factors that make adjustment more likely and profitable, in order to qualify for new loans. In a "pooling" equilibrium, deserving countries will be denied mutually-beneficial packages. In a "separating" equilibrium, countries will have to invest in costly signals to qualify for these packages. In either case, some efficient outcomes will be ruled out.

The IFIs themselves cannot observe perfectly all the relevant debtor characteristics. But perhaps they are somewhat better at this than the banks themselves, in view of the monitoring and analysis undertaken by their desk economists. To the extent that IFIs can disseminate "harder" information, then, they would allow some deals to be struck which may have otherwise been missed.

Finally, consider the effect of conditionality on the debtor's welfare. 
The government's welfare is increasing in $\mathrm{L}$ as long as it remains credit constrained, and it is also increasing in B in the no-overhang regions. (In the presence of overhang, B does not affect anything.) Therefore, the government becomes better off as we move in the northeast direction in Figures 1 and 2. As long as banks would have chosen not to offer a deal in the absence of conditionality, the government is always at least as well off with conditionality as without. In this instance, conditionality benefits the debtor because it provides it with an ability to precommit, and therefore undoes the damage caused by the dynamic inconsistency in adjustment policy. Note, however, that when creditors move first and can make a take-it-or-leaveit offer, they can cream off the entire surplus from the debtor: when the debtor gets the offer $\left(\mathrm{L}_{c}^{*}, \mathrm{~B}_{\mathrm{c}}\right)$, it is indifferent between not having a deal and adjusting.

There is also another possibility. Let us suppose that a point like $X$ in Figure $1(b)$ is indeed feasible, in the sense that banks would have offered such a package in the absence of IFIs. With conditional lending, the banks can now do better, and offer a package that consists of lower $L$ and lower $B$. The upshot is that banks are better off, but the debtor government is now worse off. In this case, banks would have been willing to "bribe" the government to adjust, and conditionality reduces the needed bribe. Note that banks will now have the incentive to "game" against the IFIs, trying to draw them into the action. Unlike in the previous case, the debtor is harmed if they succeed.

Therefore, it is not a foregone conclusion that conditionality and IFI involvement will improve the outcome from the perspective of the banks and the debtors alike. The debtors, in particular, can be made worse off. The essential criterion is whether banks would have been willing to come up with a 
package in the absence of IFIs. If they would not have. IFIs will improve matters for both sides as long as there are genuine efficlency gains in the first place. If they would have, IFIs must set conditions to ensure that the gains are not appropriated disproportionately by the banks.

\section{v. The Design of DDSR and Hew Koney Packages then IFIs are Imvolved}

One point has been finessed in the discussion so far. Does IFI conditionality actually require lending by IFIs? Why could IFIs not simply put their imprimatur on adjustment programs and monitor whether the programs are being implemented, without lending money? After all, once conditionality is in place, commercial banks should be willing to come up with the requisite new lending, as discussed above, provided there are efficiency gains.

Yet a situation in which IFIs provide only conditionality and no money of their own is unlikely to be acceptable either to the banks or the debtor government. Consider the banks first. They are likely to be suspicious of the quality of the monitoring provided by the IFIs if the latter have little incentive to do a good job of it. They will naturally want IFIs to place their own resources at risk as well as the banks'--i.e., to put their money where their mouth is. The debtor governments, on the other hand, are less likely to accept conditionality imposed by a foreign institution, with all the meddiling in domestic policy that this entails, if conditionality comes without any resources directly attached to $1 t$. It is often suspected that IFIs do the commercial banks' dirty job for them; if conditionality comes without money, what better proof could there be that this is indeed the case?

Another reason why the IFIs provide money is to protect their previous exposure. Remember that the primary motivation banks have in lending good money after bad is that this may improve the chances of recovering previous 
debts. Now when the IFIs also start out with some exposure to the problem debtor, they have similar incentives.

Consequently, any realistic sort of conditionality will require lending from the IFIs. Let us suppose that the proportion of the loan I supplied by IFIs is $\gamma$, with $(1-\gamma) L$ provided by the banks. We can see from tables 1 and 2 that the IFI's' and bilateral lenders' shares of new money was larger than that of commercial lenders, proportionally to exposures. As a result, their share of total debt increased over time. The question is how different types of arrangements divide the burden of new finance and debt reduction and the future payoff between the two categories of lenders. To build intuition, we start with the case where the IFIs have no prior exposure to the problem debtor.

(i) IEIs have no prior exposure

Consider the return to the IFIs when $L=L_{c}^{*}$, the minimum amount of new money needed to get the debtor to adjust. When the overhang is eliminated, which occurs when the commercial banks provide DDSR of exactly $B^{*}{ }_{c}$, the IFIs are repaid in full, and they get $\gamma \mathrm{RL}^{*}{ }_{\mathrm{c}}$. If banks provide DDSR of less than $B^{*}{ }_{c}$, the country adjusts but remalns in overhang, whIch means that IFIs get only a pro-rated share of repayments, $\left[\gamma L^{*}{ }_{c} /\left(D-B+L^{*}\right)\right][\alpha Y(1+\theta)]$, which falls short of full repayment. In the latter case, IFIs effectively end up subsidizing the banks. For this cross-subsidy to be avoided, it is necessary that banks provide sufficient debt reduction (here $B^{*}{ }_{c}$ ) to eliminate the overhang. In other words, for IFIs to make the "normal" return on their loan, the banks must be willing to complement their action by a debt reduction that is large enough to eliminate the overhang.

Banks would then be worse off compared with the case where they are subsidized by IFIs, but be better off compared with the case where IFIs stay 
$-34-$

on the sidelines. To see the first part of this statement, note that the returns to the banks when the overhang is elfminated through debt reduction is $R\left[D-B{ }_{c}\right]=\alpha Y(1+\theta)-R L^{*}$. The appropriately pro-rated returns when overhang prevalls is $\left(\left[D+(1-\gamma) L_{c}^{*}\right] /\left(D+L_{c}^{*}\right)\right\}[\alpha Y(1+\theta)]$. With a little bit of algebra, it can be shown that

$$
\alpha \mathrm{Y}(1+\theta)-\mathrm{RL}_{\mathrm{c}}^{*}<\left\{\left[\mathrm{D}+(1-\gamma) \mathrm{L}_{\mathrm{c}}^{*}\right] /\left(\mathrm{D}+\mathrm{L}_{\mathrm{c}}^{*}\right)\right\}[\alpha \mathrm{Y}(1+\theta)\}
$$

for any feasible value of $\gamma$, since $R\left[D+L_{c}^{*}\right]>\alpha Y(1+\theta)$. Therefore, banks would actually prefer to maintain the debtor in overhang when IFI conditionality buys adjustment, as this is a way of transferring resources from the IFIs to themselves. However, this requires that IFIs be willing accept less than the market (or normal) return on their lending to the debtor.

To see that banks are still better off having a deal even when IFIs require them to undertake sufficient debt reduction to eliminate the overhang, note that $R\left[D-B^{*}\right]=\alpha Y(1+\theta)-R^{*}{ }_{c}>\alpha Y$, since $L_{c}^{*}<\alpha \theta Y / R$ as long as efficiency gains exist from a debt package (cf. $\left[10^{\prime}\right]$ ).

If $L>L_{c}^{*}$, so that the debtor shares in the efficiency gains also, we must have $B>\mathrm{B}^{*}$, to ensure elimination of the overhang. In this case, each additional dollar of new money has to be matched by a dollar of debt reducticn (see Figure 2).

\section{(ii) IFIs have prior exposure}

Let us denote the proportion of Initial debt held by IFIs by $d$. We will now derive the set of bargains that are avallable to the commercial creditors and IFIs.

We start by noting that when conditionality is imposed, debt reduction does not affect the adjustment behavior of the debtor country. It only changes the distribution of the future debt service between creditors. Creditors that 
$-35-$

offer debt reduction in effect reduce their future clalm on the pool of resources to be paid out, $\alpha Y(1+\theta)$. Unless the IFIs get a large enough return on their involvement, they can threaten to withhold support. Similarly, unless the banks get a large enough share of the pie, it would be in their interests to remain on the sidelines. Generally, there is a large set of arrangements that satisfy these two constraints.

We first derive the IFIs' participation constraint. The IFIs will not impose conditionality and finance a share $\gamma$ of the new money required unless their payoff is not decreased in the operation. This rule is likely to apply even when it is taken with a grain of salt. In reality, the IFIs may care less about profitability than about certain other developmental goals. But in the long run, some measure of profitability must certainly be part of their objectives. We simply assume that IFIs' participation occurs whenever:

$$
d \alpha Y \leq d^{\prime} \alpha Y(1+\theta) \cdot \gamma R L,
$$

where $d^{\prime}-(d D+\gamma L) /(D-B+L)$, the post-deal IFI exposure. The inequality is satisfied whenever the net return to IFIs with the package exceeds (or equals) the net return without. This defines the combination of minimum debt relief, $B$, and maximum share in new loan, $\gamma$, that is necessary for IFIs to get involved. Setting the inequality to zero, we get the IFIs' indifference frontier shown in figure 3 :

$$
B^{m i n}=B(\gamma, L, d, \alpha, \theta)
$$

Note that $B^{\text {min }}$ can be zero when $d$ is large enough, and $L$ and $\gamma$ are small enough. 
$-36-$

Similarly, the banks' participation constraint requires that they do better with the program than without, 1.e., that:

$$
(1-d) \alpha Y \leq\left(1-d^{\prime}\right) \alpha Y(1+\theta)-(1-\gamma) R L-R B P^{\prime},
$$

where $p^{\prime}$ is the expected ex post price of debt, given by:

$$
P^{\prime}=\alpha Y(1+\theta) / R[D-B+L]
$$

This defines the maximum comination of relief, $B^{\max }$, and new loans that $c$ an be offered by banks. We have:

$$
\begin{array}{r}
++\cdots \\
B^{\max }-B(\gamma, L, d, \alpha, \theta)
\end{array}
$$

The acceptable combinations of $(B, \gamma)$ are represented in figure 3 . All the points between the banks' $\left(B^{\max }\right)$ and the IFIs' $\left(B^{\min }\right)$ reservation constraints are a priori feasible. In general, the higher the share of new loans financed by the IFIs, the larger the required debt relief from the banks.

We now investigate a particular division of the gains of the program betwen the two classes of creditors, called the proportional distribution rule (PDR). Under PDR, financial net payouts must be shared in proportion to initial exposure. Although this may also be viewed as a "fair burden sharing rule", there is nothing inherently fair about it. In reality, the efficiency gains generated by IFIs' conditionality have to be split between three parties: the country, the banks, and the IFIs themselves.

Define $p$ as the pre-deal secondary-market price, $p-\alpha Y / R D$. The net financial gains of the program, $T$, are given by the difference between the 
capital gains on the existing stock of debt $R D\left(p^{\prime}-p\right)$ and the capital losses on the new loans $R L\left(1-p^{\prime}\right)$ and on the forglven debt RBP'. It can be checked that the net financial gain $T-R D\left(p^{\prime}-p\right)-R L\left(1-p^{\prime}\right)-R B p^{\prime}$ is equal to the real gain, $\alpha \theta Y-R L$, using the definitions of $p$ and $p^{\prime}$. Since the IFIs do not engage in debt relief, their net payout, $I$, is given by the difference between a share $d$ of the total capital gains, and a share $y$ of the loss on new loans. PDR requires that:

$$
d-I / T-\left[d D\left(p^{\prime}-p\right)-\gamma L\left(1-p^{\prime}\right)\right] /\left[D\left(p^{\prime}-p\right)-L\left(1-p^{\prime}\right)-B p^{\prime}\right]
$$

which can be rewritten as:

$$
B / L-[(\gamma-d) / d]\left[\left(1-P^{\prime}\right) / P^{\prime}\right]
$$

Because all creditors share proportionally in the net financial gain under PDR, their net payoff per dollar of exposure is the same. To see that, note that the payoff per dollar of exposure for the IFIs is given by $[I+d D p] / d R D$, which under fair burden sharing (1.e., using [12]), is equal to:

$$
[T d+d D P] / d R D-[\alpha Y(1+\theta)-R L] / R D=T .
$$

Similarly, it is easy to check that the banks also get a payoff of + per dollar of initial exposure. T can be interpreted as the "fair" exit price, and it is given by the future payoff per dollar of debt if the country adjusts, net of the present value of the required new loans. Equation (12') can be used to derive some implications of PDR:

(i) When $\gamma-d, i . e$. , when the new loan is provided by the IFIs in proportion 
to their initial exposure, debt reduction is unnecessary, i.e., B -0 . The intuition for this result is simple: when the sharing of the burden of providing new loans is "fair", the sharing of the future payoff will also be "fair". In these circumstances, it would be "unfair" to ask the commercial creditors for some further contribution in terms of debt relief. (ii) When $\gamma>d$, that is, when the IFIs provide a more than proportionate share of the new money, then $B$ must necessarily be positive. In this situation, banks must bear an additional burden to make up for their proportionally small loss on the new loan. This can be done by restricting the banks to get a smaller share of the future payout. Debt (and debt service) reduction is such a mechanism. This rule can be also turned around: when banks offer debt relief, PDR requires that this loss be made up by their provision of a smaller than proportionate share of the new loan L.

(iii) As long as $d>0$ and $\gamma>d$, the debtor must remain in overhang after the debt deal is completed. The reason is that when $d>0$, the IFIs must also share the burden. But since they do not provide debt reduction, they would remain whole unless the new price of debt, $\mathrm{p}^{\prime}$, remains below unity. This can also be seen from equation (12): as $P^{\prime}$ goes to 1 , the RHS goes to $d D(1$ $p) /[D(1-p)-B]$ which is larger than $d$. For the same reason, banks cannot be asked under PDR to provide all the debt reduction needed to return the debtor to full creditworthiness.

In practice, the secondary-market discount rarely disappears following Brady-type deals. This is consistent with the above, in that the overhang should disappear under PDR only in the case where the IFIs have no initial exposure to the debtor country. But there may be other reasons why the debt price will not go to unity after a debt deal is completed. One possibility is that perhaps IFIs are subsidizing the banks. In this interpretation, IFIs have 
$-39-$

not been forceful enough in asking for more debt reduction on the part of the banks. Moreover, we have so far assumed that IFI participation buys conditionality with certainty. In practice, doubts may remain as to the quality of the conditionality, and these would be reflected in the secondary market discount.

Finally, we discuss the determinants of the country's welfare. As argued above, the country could lose if unconditional lending would have occurred in the absence of IFIs. It could thus try to bargain for liquidity above I." in order to enter a program (and possibly as large as $\mathrm{L}^{*}$ ). Note that although debt reduction does not directly affect economic behavior in the debtor economy but rather redistributes the burden of financing adjustment between different creditors, there may still be indirect effects. When the creditors are locked together in bargaining, there is uncertainty in the country as to whether an adfustment program with external financial support will materialize. This depresses economic activity. A debt reduction agreement signals that the burden sharing issue has been resolved and that an adjustment program with adequate support will materialize. The announcement effect then has positive value to the extent that the country gains from such a program.

\section{Brady Deals}

We now turn to schemes which are closer to actual Brady deals, in which IFIs provide the resources to retire a portion of the debt (at some price below par) as well as additional adjustment loans. In the "pure" debt reduction schemes discussed above, we were assuming that this debt repurchase was taking place at a price of zero. More generally, the repurchase will take place at a negotiated price, $\delta$. What we will show is that by setting appropriately a price and a level of debt repurchase, the efficiency gains can 
$-40-$

be divided between the banks and the debtor in any desired manner.

We suppose that the debt package has the following components:

(1) an adjustment loan of $\gamma \mathrm{L}^{*}$, from the IFIs, in return for conditionality;

(ii) a loan to the country from IFIs of $\delta B$, to be used in retiring $B$ amount of debt at price $\delta(<1)$;

(1ii) agreement on the part of the banks that they will put up new money of $(1-\gamma) \mathrm{L}^{*}$ and will sell off $B$ amount of debt at price $\delta$.

We will take $\gamma$ here as given, and look at different pairs of $\delta$ and $B$ to see how the deal can be structured to split the gains.

The "participation" constraints of the IFIs and the creditor banks now also depend on the exit price $\delta$. The IFIs will not participate in the deal unless $B \geq B^{\min }-B(\gamma, L, d, \alpha, \theta, \delta)$, with $\partial B^{\min } / \partial \delta>0$ as long as $\delta$ is small enough. When $\delta$ is close enough to $\mathrm{P}^{\prime}$, the IFIs will be losers. (This is discussed more formally below in the context of the proportional distribution rule.) This is represented in figure 4. The analogous participation constraint for the banks is now given by $B \leq B^{\max }-B(\gamma, L, d, \alpha, \theta, \delta)$, with $\partial \mathrm{B}^{\max } / \partial \delta>0$ for $\delta<\mathrm{P}^{\prime}$. Of course, when $\delta$ exceeds $\mathrm{P}^{\prime}$, banks will be happy to sell more debt. Note that the minimum price at which banks are willing to sell the entire debt stock is the pre-deal market price, $p-\alpha Y / R D$. The range of feasible, mutually-advantageous programs is represented by the shaded area in Figure 4 . The closer we move to the $\mathrm{B}^{\mathrm{min}}$ schedule, the more beneficial to the banks' interests does the program become. The figure shows the general tendency for the requisite amount of debt reduction to increase as the repurchase price rises. We also note from Figure 4 that banks are willing to "sell off" as much as $B^{b}$ of debt at a price zero (that is, pzovide pure debt reduction of $\mathrm{B}^{\mathrm{b}}$ ). Debt buybacks at any price above $\mathrm{B}^{\mathrm{m} 1 \mathrm{n}}$ transfers resources to the banks. This is akin to the Bulow-Rogoff argument against partial buybacks 
-41 -

at the market price. But the crucial story here is the distribution of efficiency gains.

Finally, we repeat the application of the proportional distribution rule to this case, when debt reduction is costly. The cost of debt reduction $B \delta$ is financed by the IFIs in addition to their contribution of a share $y$ of $L$ (note that there are limits on the ratio $B \delta / \gamma \mathrm{L}$, set at the Bank and the Fund between 20-25 percent). The PDR rule now requires that the IFIs share of debt, $d$, be set equal to:

$$
\begin{aligned}
d D\left(p^{\prime}-\delta\right)-\gamma L\left(1-p^{\prime}\right)-B \delta\left(1-p^{\prime}\right) \\
\quad-\left(p^{\prime}-\delta\right)-(L+B \delta)\left(1-p^{\prime}\right)-B\left(p^{\prime}-\delta\right)
\end{aligned}
$$

where $p^{\prime}$ is now given by

$$
\mathrm{p}^{\prime}-\alpha \mathrm{Y}(1+\theta) / \mathrm{R}[\mathrm{D}-\mathrm{B}(1-\delta)+\mathrm{L}] \text {. }
$$

Some algebra leads to:

$$
B / L-\left[\left(1-p^{\prime}\right)(\gamma-d)\right] /\left[d p^{\prime}(1-\delta)-\delta\left(1-p^{\prime}\right)\right],
$$

which is equal to $\left(12^{\prime}\right)$ when $\delta-0$. As $\delta$ increases, B increases as well. The intuition is that banks are getting an early payoff compared to the pure rellef case. As a result, the IFIs require a larger share of future earnings, and this is done with larger buybacks. This can only work as long as $\delta<p^{\prime}$, and the Implied B 1s smaller than (1-d)D. At some $8^{\max }<p^{\prime}$, all the commerclal debt would need to be retired. ${ }^{5}$ One important implication is that PDR is 
incompatible with $\delta$ being set equal to $\mathrm{p}$ ". That is, the "fair" exit price lies below the post deal market price.

Finally, note that the larger $(\gamma-d)$ is, $1 . e$, the more asymetric is the sharing of the new loans, the lower is $\delta^{\max }$. Thus, the more unfair the distribution of new loans is, the smaller must be the price at which debt is retired.

If debt is repurchased on the secondary market, then the price that must be paid is the equilibrium price of debt claims after the debt reduction, $\mathrm{p}^{\prime}$. As a result, deals that require proportional burden sharing (PDR) cannot rely on market buybacks to achieve the desired debt reduction. Rather, concerted debt reductions must be worked out to overcome this coordination failure. Ideally, each creditor bank would sell a specific share of its claims at a price below the expected ex-post price $p^{\prime}$. In practice, this may prove difficult since free-riding remains the dominant strategy for each bank. But any amount of coordination would still represent an improvement over the market approach.

A more important problem with the concerted approach is caused by heterogeneity within the banks' group. If creditors differ with respect to

5. Rewrite $(16)$ as $G(B, \delta)=-P^{\prime}(B)[L(\gamma-d)+B d(1-\delta)+B \delta]+L(\gamma-d)+B \delta-0$; we have: $\partial B / \partial \delta-G_{p} / G_{B}$, where $G_{p}-B\left[1-p^{\prime}(1-d)\right]>0$, and $G_{B}-\left(\partial p^{\prime} / \partial B\right)[L(\gamma-d)+B d(1-$ $\delta)+B \delta]-p^{\prime}[d(1-\delta)+\delta]+\delta$, which is negative when $\delta$ is small, and equal to zero when $\delta$ reaches $\delta^{\max }<\mathrm{p}^{\prime}$. Note that as $\gamma$ gets smaller, there is more room 
their own valuation of country debt, a concerted buyback that does not discriminate among banks and that at the same time hurts no bank must occur at the reservation price of the bank with the highest valuation. Attempts to discriminate between creditors require unobservable information and create moral hazard. On this score, the market mechanism is more efficient in that it allows creditors to self-select, with only those with low valuation selling out at a particular offer price.

\section{The Kenu Approach and Burden Sharing Among Creditor Bants}

Recent agreements have focused on a menu of options from which the creditors will select later. An agreed upon menu is a contract, which may be partly implicit, establishing a future opportunity set for the lenders. The menu approach requires that lenders commit to choose from a restricted set of options ex post. By combining concerted and voluntary characteristics, the menu approach to debt reduction retains the advantages, but not the inconveniences of pure market and pure concerted mechanisms described above. The options on the menu and their relative pricing are negotiated first; in a second round, each creditor freely chooses his preferred option. Overall, the discrimination allowed by the menu allows for larger actual relief, for a given willingness of banks to offer relief (see Diwan and Spiegel [1990) for a formal treatment).

For a menu of options to allow different creditors to choose different options voluntarily, the value of all options must be comparable. Interestingly, this works out mechanically when the menu includes exit and relending options, because each of these options becomes more valuable as the other option is picked by too many banks. In equilibrium, all options will have comparable values. To illustrate this claim, we develop below the 
$-44-$

equilibrium analysis for the simplest case where all banks are simflar.

Suppose that the creditors (including the IFIs) have agreed with the debtor country on a simple menu of options represented by the pair $(\delta, n)$ : for each dollar of claim they hold, creditors can choose to either exit at a price of $\delta$, or to reschedule the loan and relend $n$ dollars in addition. To see that in equilibrium both options will have the same value, let $D_{1}$ stand for debt stock after the completion of the exchange and $N$ for the total amount of new money. We have:

$$
\begin{aligned}
& D_{1}=R[D-B+N] \\
& P^{\prime}-\alpha Y(1+\theta) / D_{1} \\
& n-N /[D-B]
\end{aligned}
$$

Lenders choose between the two options in a manner that maximizes the value of their assets subject to the terms of the menu $(\delta, n)$. After the deal is completed, debt prices are expected to be higher at $\mathrm{p}^{\prime}>\mathrm{p}=\alpha \mathrm{Y} / \mathrm{KD}$. t. creditor that relends $\mathrm{n}$ dollars will have its old claim revalued. However, its new claim $n$ will be only valued at $\mathrm{p}^{\prime}$, implying a capital loss of ( 1 - $\left.\mathrm{p}^{\prime}\right)$. Thus, the opportunity cost of holding a unit of debt back from repurchase at price $\delta$ is $P^{\prime}(1+n)$ - $n$. This implies that when $P^{\prime}$ exceeds $(\delta+n) /(1+n)$, the new money option is preferred to the exit option. Thus, less debt will be sold and more new money offered, resulting in less than expected debt reduction. This leads to an increase in $D_{1}$ (using eq. (17)), and thus to a reduction in $p^{\prime}$ (using eq. [18]). Since creditors are price-takers when they optimize ex post, and because the expected present value of debt $p^{\prime}$ is strictly concave, the 
$-45$.

solution to portfolio value maximization by creditors is unique. In equilibrium, we must then have:

$$
p^{\prime}-(\delta+n) /(1+n)
$$

The system of equations (17) to (20) can be solved for $B, N, D_{1}$ and $P^{\prime}$ as a function of any menu $(\delta, n)$. Any menu $(\delta, n)$ will produce an equilibrium $(B, N)$ in which all the credltors, whether they exit or relend, retain a net payoff exactly equal to $\delta$. Thus, all menus $(\delta, n)$ involve a proportional distribution of the net gains. In particular, if the menu is offered to all creditors, IFIs as well as commercial banks, a proportional sharing of the burden across both classes of creditors will be achieved, and the requirements of PDR will be necessarily satisfied. (Once again, we leave aside the question of whether this involves a "fair" burden' sharing or not.)

But for a menu to be able to support the conditional adjustment program, $(\delta, n)$ should be set so that sufficient new loans are raised to finance both the adjustment, $L_{c}^{*}$, and the buybacks, $B \delta$. Which menus raise exactly $L_{c}^{*}-$ $(N-\delta B)$ ? To answer this, feed equations (17) and (18) into (20), he have:

$$
\begin{aligned}
a Y(1+\theta) / R(D-B+N) & -(\delta+n) /(1+n) \\
& =(\delta+[N /(D-B)] 1 /[1+(N /(D-B))]
\end{aligned}
$$

using (19), which implies that $a Y(1+\theta)-R\left(\delta D+L^{*}{ }_{c}\right\}$ when $N-\delta B$ is set equal to $L^{*}$. Solving for $\delta$, we get $\delta=\left[\alpha Y(1+\theta)-R L{ }_{c}\right] / R D=T$, using (13).

Thus, when $\delta$ is set equal to the "fair" exit price $r$, any $n$ will produce a menu that raises on a net basis exactly $L{ }_{c}$. That $\delta-r$ is necessary to achieve a menu deal that raises $L^{*}$, of net financing is not surprising 
$-46-$

becasue both options must have the same value, and because proportional burden sharing with sufficient financing leaves a payoff of + per dollar of initial debt. What is more surprising is that when $\delta-r$, the only effect of varying $n$ is to increase the equilibrium volume of both buybacks and new money, but with no net effect on the liquidity $L$ that is raised.

To see this more clearly, we analyze how the equilibrlum $(B, N)$ and the net financing raised $N-\delta B$ vary as the new money call, $n$, is increased. We do not impose that $N-\delta D$ be equal to $L_{c}^{*}$. Rather, we look for the effect of the menu on the amounts raised. Differentiating (21) with respect to $n$ and rearranging, we get: $\partial N / \partial n-[\alpha Y(1+\theta)-N] /(\delta+n)>0$ for $n$ small enough.

The effect of $n$ is ambiguous. On the one hand, as $n$ increases, new money is increased for any given choices by banks. But on the other hand, an increase in $n$ makes exit more desirable and thus reduces the base for the new money call. The total effect is positive as long as $n$ does not exceed some maximum level (the country would not want to be on the declining part of the new money curve). The importance of this result for our purposes is that when IFIs are keen on delivering their share of the burden in the form of new loans rather than in the form of debt reduction, then $n$ should be set large enough to lead to an equilibrium with a new money contribution that is large enough to accomodate their exposure. Given banks preferences between the two instruments, a larger exposure of the IFIs should lead to a larger $n$ under proportional burden sharing.

Similarly, to see the effect of $n$ on the amount of debt reduction achieved in equilibrium, differentiate ( 8 ) with respect to $n$ to get: 


$$
\partial B / \partial n--[(\partial N / \partial n) n-N)] / n^{2}>0
$$

The equilibrium amount of debt reduction is increasing in $\mathrm{n}$. As the new money call, $n$, is increased, the exit option becomes more desirable than the relending option. But, in equilibrium, both options must be equally desirable. As a result, a larger debt reduction will be achieved in order to raise further the ex post debt price $p^{\prime}$ and increase the attractiveness of the relending option.

Consequently, increasing $n$ leads to larger buybacks and larger new money in equilibrium. What is the net effect on the liquidity received (N- $\delta B)$ ? Using (22) and (23), we find:

$$
\partial(N-\delta B) / \partial n-(D / n)(\tau-\delta) \geq 0 \text { as } r \geq \delta,
$$

and therefore the amount of net funds recelved is invariant to $n$ when $\delta \rightarrow r$, 1.e., under proportional burden sharing. Thus, the only effect of a change in $\mathrm{n}$ is indeed to accomodate different set of preferences of the creditor group.

\section{Concluding Renarks}

This paper has covered a lot of ground. We have tried to present a framework in which the roles of the debt overhang, adjustment lending with conditionality, and of Brady-type arrangements involving new money and debt and debt-service reduction could be understood and evaluated.

Our starting point has been the observation that the chief inefficiency engendered by the existence of an overhang is the inability of debtor countrles to finance desirable investments, including adjustment programs, due 
to lack of liquidity. We first focused on the adjustment decision of the debtor government. We showed that a credit-constrained government will undertake an adjustment program that has immediate costs but eventual benefits only if sufficlent amount of external lending is available. Since the adjustment program benefits creditors as well (through higher debt service), it is possible that commercial banks would finance the program on their own. However, we showed that the amount of new lending required to "purchase" adjustment in the absence of conditionality (that is, without the involvement of IFIs) can be much laxger than the corresponding amount when conditionality is present. Adjustment lending with conditionality therefore greatly expands the set of efficiency-increasing bargains between creditors and debtors.

We next turned to the implications of IFI participation for the design of a debt package. We focused here on a proportional distribution rule (PDR) undex which net returns to different creditors are shared in proportion to Inftial exposure to the debtor. Under such a rule, adjustment lending by IFIs requires debt or debt service reduction by commercial banks. This is true whenever the IFIs' share of new money exceeds their share of the outstanding debt stock, as has been the case throughout the 1980s. The point of DDSR in our framework is not to create appropriate incentives for the debtor, as in much of the overhang literature, but to ensure that IFIs and commercial creditors are treated equitably. Debt reduction creates the "headroom" required for the more efficlent lenders (IFIs) to come in without subsidizing other creditors.

We also showed, however, that the PDR precludes a complete elimination of the overhang and a full return to creditworthiness (unless the IFIs have no prior exposure whatsoever). The reason is that, if the post-deal price were to return to unity, the IFIs (which do not provide DDSR) would remain whole 
while the commercial banks would take a loss on their DDSR. For the same reason, banks cannot be asked, under the PDR, for the entire debt reduction needed to return the debtor to full creditworthiness.

We then generalized our framework to include Brady-type deals in which IFIs lend the debtor the resources needed to retire some of the debt and commercial creditors are presented with a menu of options. We showed here that PDR requires the exit price at which debt is retired to be below the post-deal price. Further, the higher the share of IFIs in the new money, the lower must this exit price be. These rule out market buybacks, as the only equilibrium price at which debt can be repurchased in a market setting is the equilibrium price after the debt reduction. This provides a justification for the concerted approach contained in Brady-type arrangements.

Some of the advantages of the market-based approach are recovered by the menus presented to commercial creditors. Such menus allow heterogeneity of banks' valuations to be reflected in banks' choices. For all options on a menu to be chosen voluntarily, the value of each must be identical. We showed that this works out naturally when the menu contains exit and new-money options, because each of these options becomes more valuable as the other option is picked by an increasing number of banks. The menu also allows us to interpret IFIs as just any other creditor group which happens to choose relending over exit. The PDR is satisfied automatically in this context, by virtue of different options being valued equally in equilibrium.

We close by noting that our analysis of debt reduction extends to all forms of new finance that provide efficiency gains. One notable example is direct foreign investment. Just as in the case of adjustment lending, it is necessary to convince prospective foreign investors that their profit remittances will not be crowded out by debt-service to existing creditors. 
$-50$.

Debt reduction represents a credible commitment on the part of banks that they will effectively allow senfority to creditors that come later. 


\section{REPEREATCES}

Borensztein, Eduardo, 1990, "Debt Overhang, Credit Rationing and Investment: the case of the Philippines" IMF working paper.

Bulow, Jeremy, and Kenneth Rogoff, 1991, "Is the World Bank a Preferred Creditor?" unpublished.

, 1990, "Cleaning up Third World Debt without Getting Taken to the Cleaners," Journal of Economic Perspectives, 4: $31-42$.

Claessens, Stijn, and Ishac Diwan, 1990, "Investment Incentives: New Money, Debt Relief, and the Critical Role of Conditionality in the Debt Crisis, "The World Bank Economic Review 4: 21-41.

Corden, W, Max, 1988, "Debt Relief and Adjustment Incentives: A Theoretical Exploration," IMF.

Demirguc-Kunt, Asli and Eduardo Fernandez-Arias, 1991, "Burden Sharing Among official and Private Creditors." Mimeo, World bank.

Diwan, Ishac, and Mark M. Spiegel, 1991, "Are Buybacks Back? Menu-Driven Debt-Reduction Schemes with Heterogeneous Creditors," The World Bank.

Eaton, Jonathan, 1990, "Debt Relief and the International Enforcement of Loan Contracts," Journal of Economic Perspectives, 4:43-56.

Froot, Kenneth A., 1989, "Buybacks, Exit Bonds, and the Optimality of Debt and Liquidity Relief," International Economic Review 30: 49-70.

Krugman, Paul, 1987, "Financing versus Forgiving a Debt Overhang: Some Analytical Notes," MIT.

Morisset, Jacques. 1991. "Can Debt Reduction Policies Restore Investment. A Macro Framework Applied to Argentina" World Bank, working paper no 691.

Ozler, Sule, and Dani Rodrik, 1991, "External Shocks, Politics, and Private Investment: Some Theory and Empirical Evidence, : unpublished paper.

Sachs, Jeffrey, 1989, "Conditionality, Debt Relief, and the Developing Country Debt Crisis," in Sachs (ed.), Developing Country Debt and Economic Performance: The International Financial System, Chicago, Chicago University Press.

Schidt-Hebbel, Klaus. 1990. "Foreign Debt, Macro Adjustment, and Growth: Brazil 1970-1988." World Bank, working paper.

World Bank, 1990. "Adjustment Lending Policles for Sustainable Growth." Policy and Research Serles No. 14. 
Table 1

Composition of Debt Stocks in the SIMICS, 1982-90

(billion of dollars and percentages)

$\begin{array}{llrccr}\text { Total } & \text { IFIs } & \begin{array}{l}\text { Official } \\ \text { Debt }\end{array} & \begin{array}{c}\text { Commercial } \\ \text { Banks }\end{array} & \text { Others } \\ 1982 & 29.4 & 7.4 & 18.9 & 63.3 & 10.4 \\ 1983 & 34.8 & 7.1 & 18.2 & 64.5 & 10.3 \\ 1984 & 37.6 & 7.0 & 18.4 & 65.7 & 9.0 \\ 1985 & 41.6 & 8.3 & 22.7 & 60.0 & 9.0 \\ 1986 & 45.6 & 10.0 & 23.2 & 58.2 & 8.6 \\ 1987 & 50.0 & 11.6 & 25.1 & 55.2 & 8.1 \\ 1988 & 50.1 & 11.3 & 24.8 & 55.9 & 8.1 \\ 1989 & 49.6 & 11.9 & 25.7 & 53.3 & 9.1 \\ 1990 & 48.2 & 13.8 & 26.1 & 44.6 & 15.5\end{array}$

Source: World Debt Tables, World Bank

Note: SIMICS stands for severely indebted middle income countries. Those are: Argentina, Bolivia, Brazil, Chile, Congo, Costa Rica, Cote d'Ivoire, Ecuador, Honduras, Hungary, Mexico, Morocco, Nicaragua, Peru, Philippines, Poland, Senegal, Uruguay, Venezuela. 
Table 2

Composition of Net Transfers in the SIMICS, 1982-90 (billion of dollars)

\begin{tabular}{|c|c|c|}
\hline $\begin{array}{l}\text { Total Net } \\
\text { Transfers }\end{array}$ & IFI & $\begin{array}{l}\text { Bilateral } \\
\text { Creditors }\end{array}$ \\
\hline
\end{tabular}

$\begin{array}{lrrrrr}1982 & 8.1 & 3.8 & 3.9 & -3.9 & 4.3 \\ 1983 & -2.4 & 8.5 & 3.1 & -13.1 & -1.0 \\ 1984 & -12.0 & 5.2 & 1.4 & -16.5 & -2.2 \\ 1985 & -19.5 & 2.7 & 0.5 & -21.1 & -1.7 \\ 1986 & -23.9 & 0.7 & -1.1 & -21.1 & -2.4 \\ 1987 & -23.1 & -3.1 & 0.0 & -16.9 & -3.1 \\ 1988 & -30.2 & -3.6 & -0.2 & -23.9 & -2.5 \\ 1989 & -24.4 & -2.7 & -2.3 & -15.9 & -3.5 \\ 1990 & -39.6 & 0.4 & -5.0 & -25.3 & -9.7\end{array}$

Source: World Debt Tables, World Bank Note: see table 1. 
Table 3

Behavior of Net Transfers by SIMICS, 1982-90

\begin{tabular}{|c|c|c|c|}
\hline \multirow[b]{2}{*}{$\begin{array}{l}\text { Independent } \\
\text { Variables ( } \$ B i 1)\end{array}$} & \multicolumn{3}{|c|}{ Dependent Variables ( $\$ B i 1)$} \\
\hline & $\begin{array}{l}\text { Total Net } \\
\text { Transfers }\end{array}$ & $\begin{array}{l}\text { Net Transfers } \\
\text { to Com. Banks }\end{array}$ & $\begin{array}{l}\text { Net Transfers } \\
\text { to Official Sector }\end{array}$ \\
\hline Total Debt & $\begin{array}{l}-0.1251 * \star \\
(0.0159)\end{array}$ & & \\
\hline Conmercial Debt & & $\begin{array}{l}-0.0997 \star \star \\
(0.0177)\end{array}$ & \\
\hline Official Debt & & & $\begin{array}{l}-0.0835 \star \star \\
(0.0172)\end{array}$ \\
\hline GDP & $\begin{array}{l}-0.0182 \star \star \\
(0.0041)\end{array}$ & $\begin{array}{l}-0.0020 \\
(0.0034)\end{array}$ & $\begin{array}{l}-0.0164 \star \star \\
(0.0020)\end{array}$ \\
\hline $\begin{array}{l}\text { Exports of Goods } \\
\text { and Services }\end{array}$ & $\begin{array}{l}0.1336 \star \star \\
(0.0470)\end{array}$ & $\begin{array}{l}0.0896 * \star \\
(0.0378)\end{array}$ & $\begin{array}{c}0.0291 \\
(0.0268)\end{array}$ \\
\hline $\begin{array}{l}\text { Dummy for IMF } \\
\text { Program }\end{array}$ & $\begin{array}{l}-80.6 \\
(246.9)\end{array}$ & $\begin{array}{l}-223.9 \\
(198.1)\end{array}$ & $\begin{array}{r}232.6 * \\
(103.5)\end{array}$ \\
\hline $\mathrm{N}$ & 171 & 171 & 171 \\
\hline$R^{2}$ & 0.84 & 0.79 & 0.57 \\
\hline
\end{tabular}

Notes:

Negative Net Transfers indicate transfers towards the creditors See also table 1

Source: World Debt Tables

Standard error in parentheses

Regressions include country and year dumnies

** significant at 1 percent level

* significant at 5 percent level 
Table 4

Adjustment Costs for Early Adjustment Countries

(percentage points)

$\begin{array}{cc}\text { Periods dummies } & \text { Loss in GDP (percent) } \\ t=-2 & -2.4 \\ t=-1 & -3.1 \\ t=0 & -5.1 \\ t=1 & -4.7 \\ t=2 & -2.0 \\ t=3 & -2.3\end{array}$

$$
\begin{aligned}
& N=125 \\
& R^{2}=11.9
\end{aligned}
$$

Notes:

The independent variable is the deviation between annual growth of per-capita GDP, adjusted for terms of trade shocks, and per-capita GDP growth trend during 1960-1980. The adjusted annual growth rate of per capita GDP is from Heston and Summers, 1988. The trend variables for per capita growth 1960-80 in each country was computed by regressing per capita growth of GDP on a time variable.

Period dummies: $t-0$ refers to the year in which an IMF program was first signed during the period 1977-87. $t--i$ refers to $i$ years before, and $t=j$ refers to $j$ years after.

Data set: Early adjustment countries are those that have received two structural adjustment loans from the World Bank, with the first operation in 1985 or before. All had IMF Stand-by agreements.

Source: Adjustment Lending Policies for Sustainable Growth. World Bank (1990). 
Table 5: Upper Bounds on $L \star \gamma$

(percentage points)

\begin{tabular}{ccccc}
\hline & \multicolumn{4}{l}{ creditors' share of ${ }^{\prime}$ income $\alpha$} \\
1 & 1 & 2 & 3 & 4 \\
\hline 10 & 0.09 & 0.18 & 0.27 & 0.36 \\
30 & 0.18 & 0.36 & 0.54 & 0.73 \\
40 & 0.27 & 0.54 & 0.82 & 1.09 \\
& 0.36 & 0.73 & 1.09 & 1.45 \\
\hline
\end{tabular}

Note: $\theta$ is the permanent increase in the level of GDP due to adjustment. 

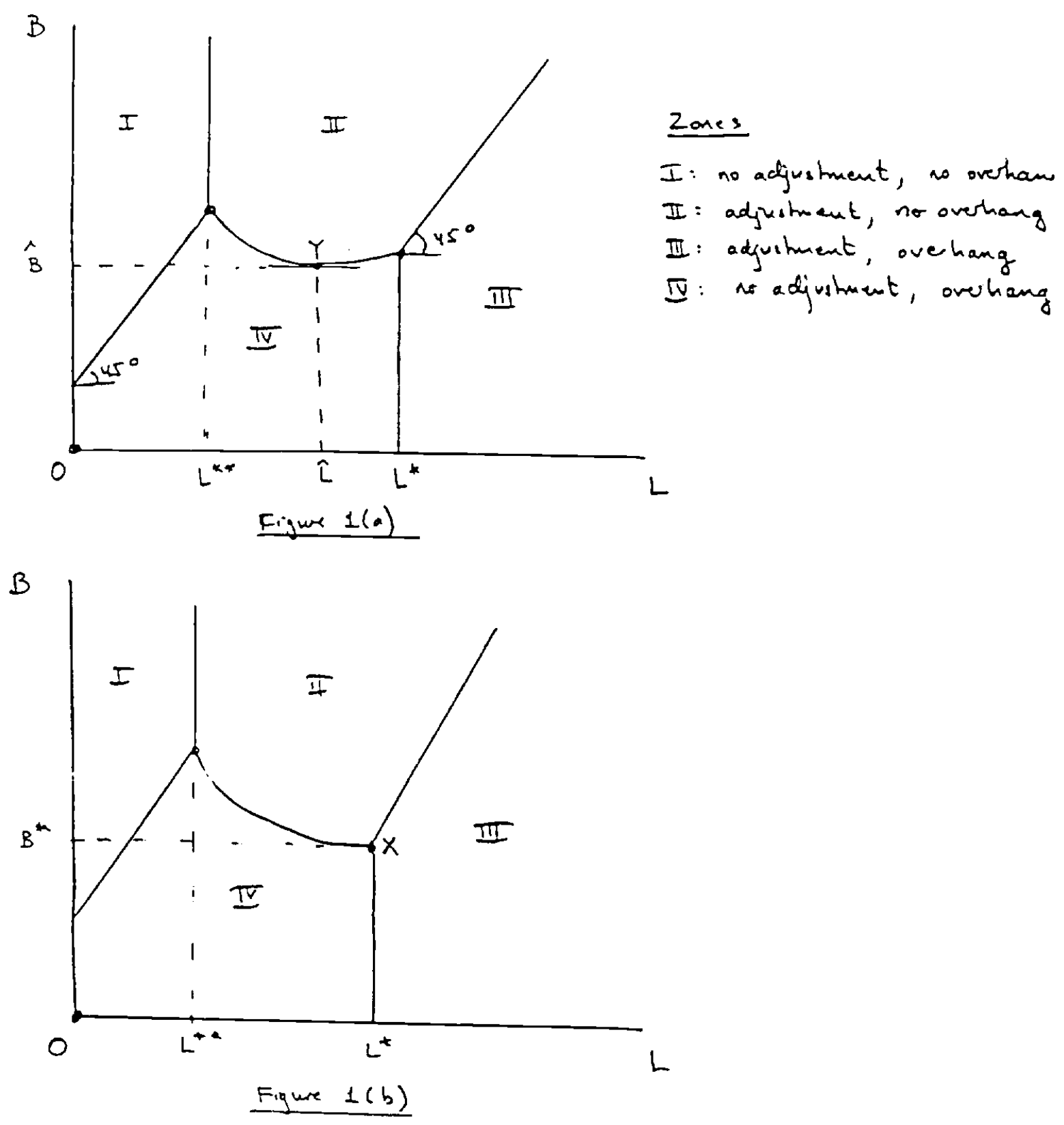


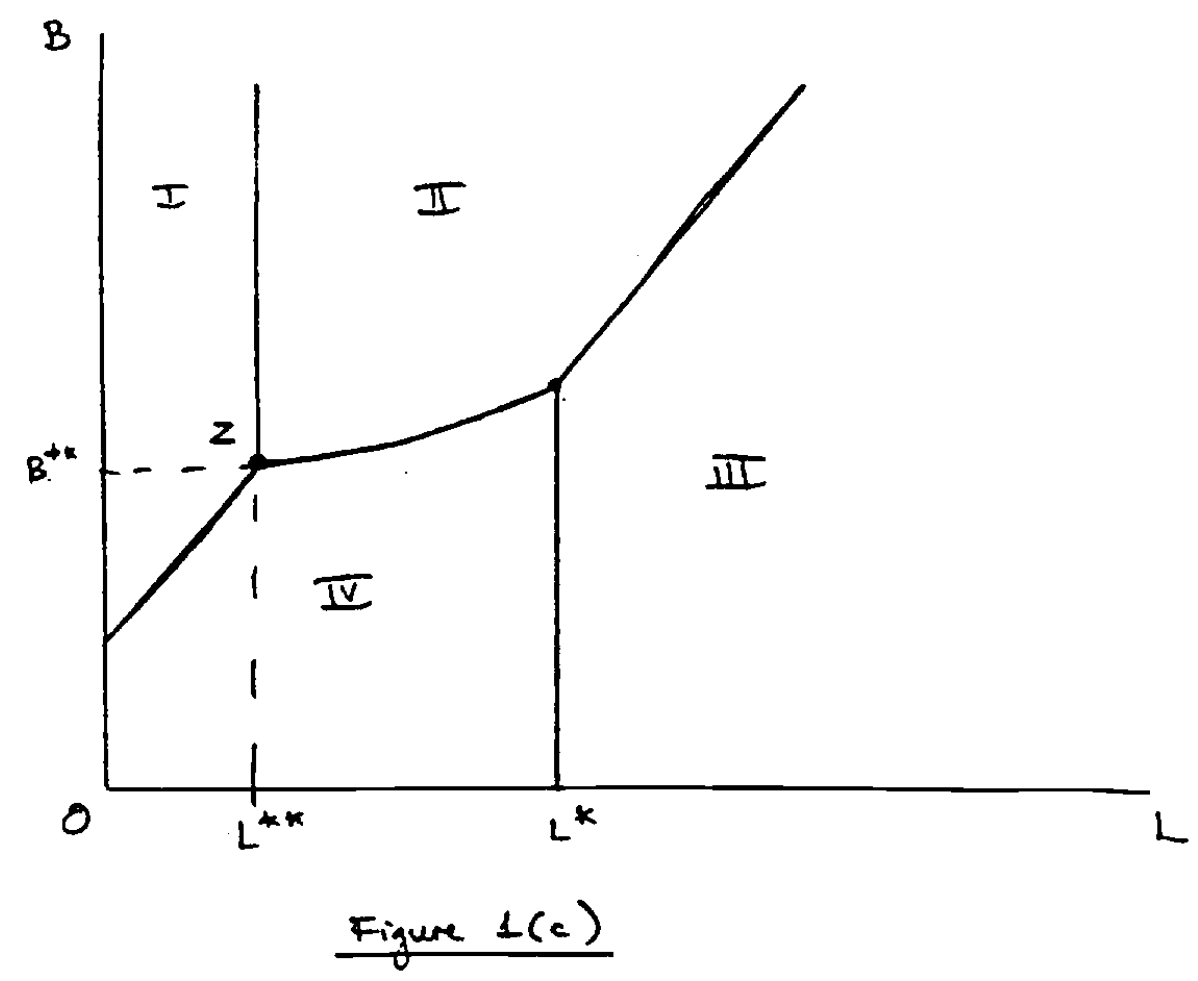




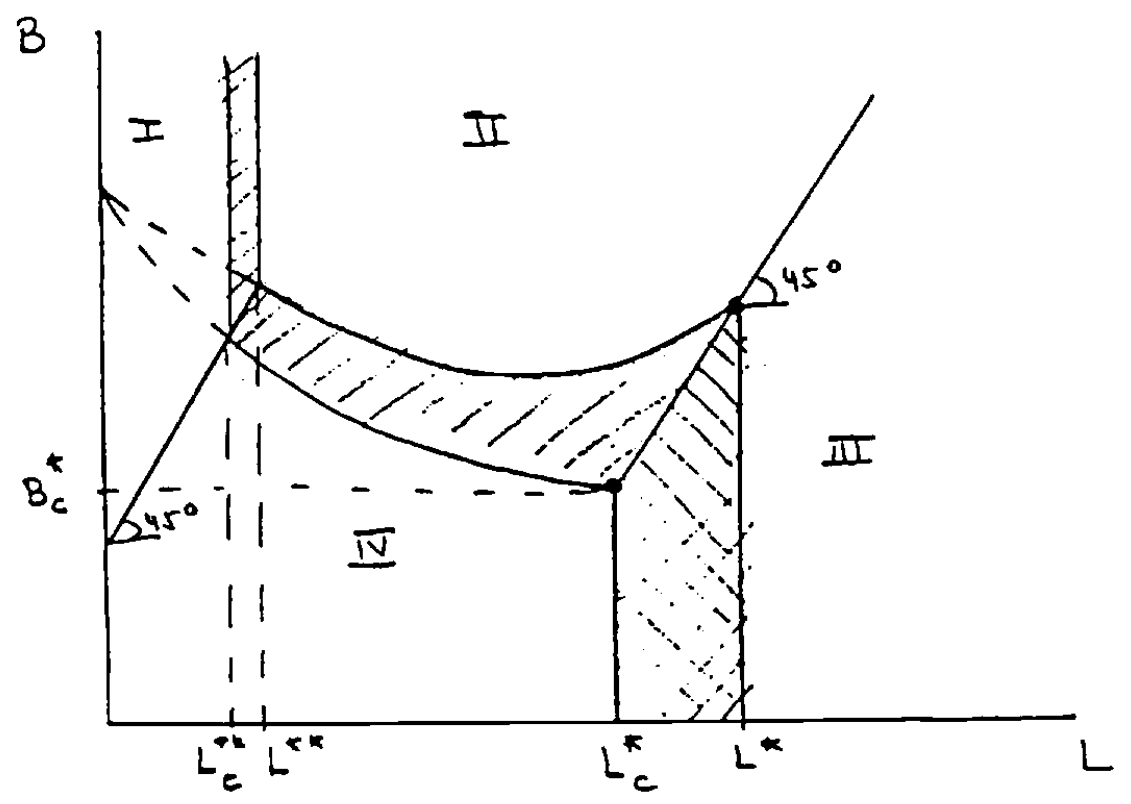

Frqure 2 
Figure 3

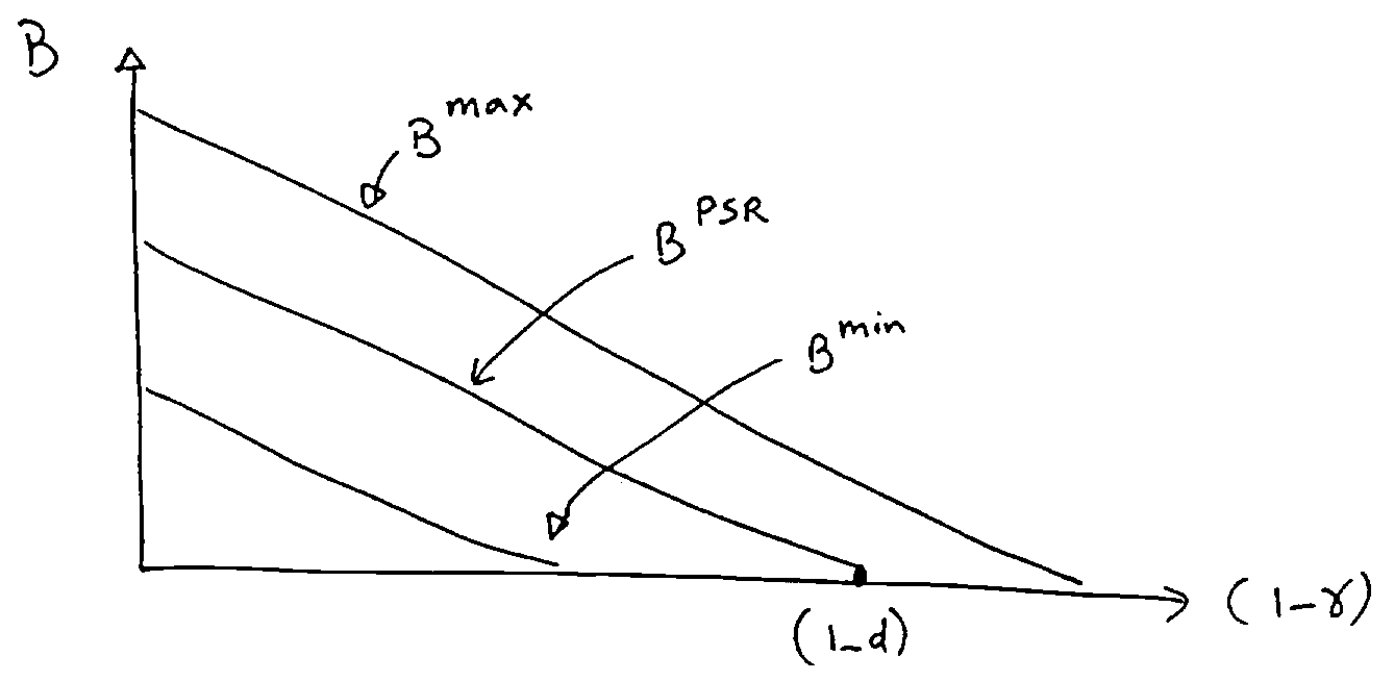


Figure 4

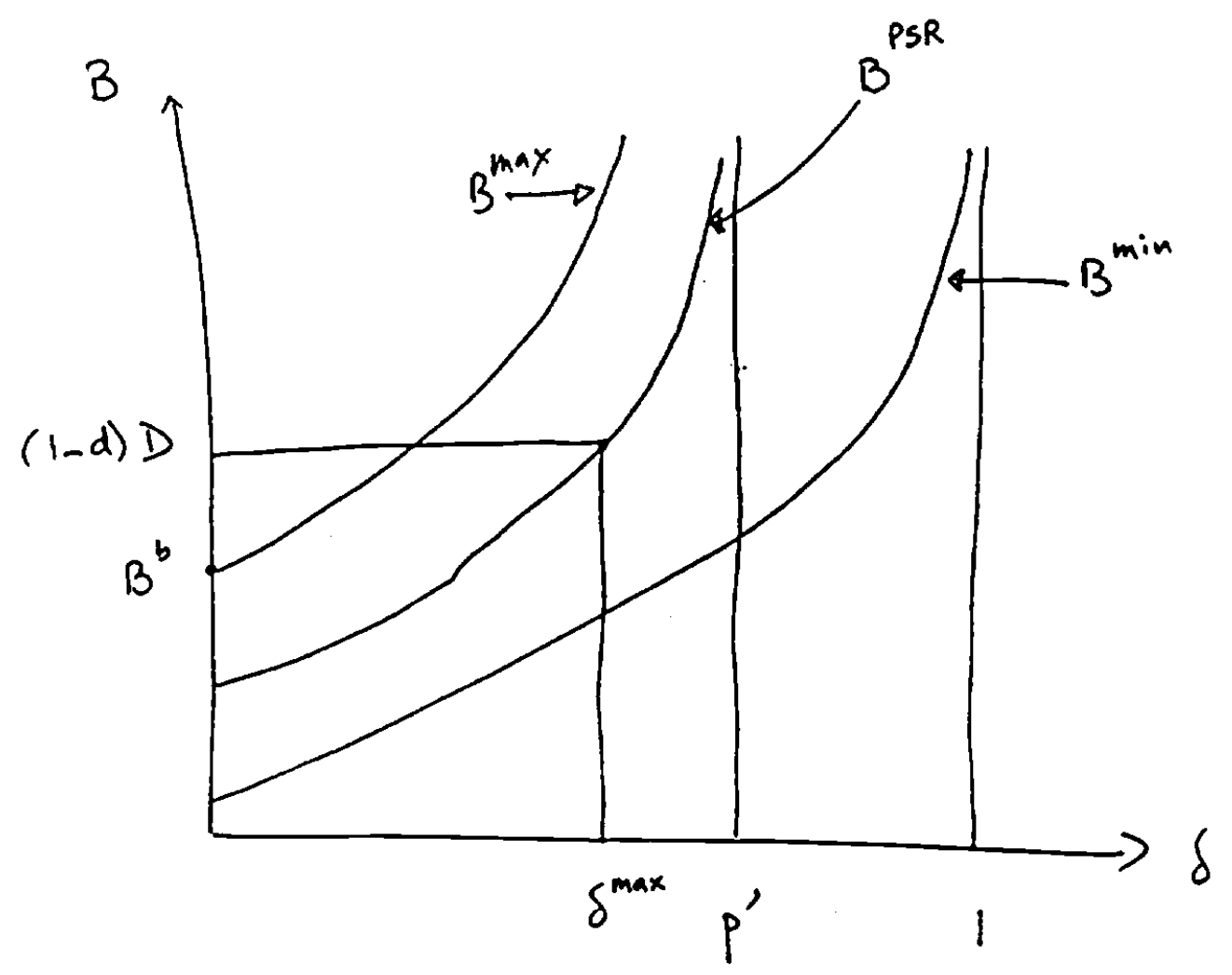

